\title{
A New Look at the Identification of Low-Level Jets in South America
}

\author{
MAurício I. Oliveira, ${ }^{a}$ ERnANi L. NASCIMENTO, AND CAROLINA KANNENBERG \\ Grupo de Modelagem Atmosférica, Departamento de Física, Universidade Federal de Santa Maria, Santa Maria, \\ Rio Grande do Sul, Brazil
}

(Manuscript received 16 August 2017, in final form 8 May 2018)

\begin{abstract}
Criteria currently employed in algorithms that identify low-level jets (LLJs) in South America utilizing rawinsonde and gridded model data fail to detect an important number of LLJ events. This study discusses shortcomings in the existing approaches for LLJ identification in South America and proposes modifications to the criteria regarding layer depth for LLJ identification and wind direction. Episodes of southerly LLJs, which have received less attention in the La Plata basin, are also included in the investigation. A sensitivity analysis of LLJ detection in South America upon the choice of the criteria applied to a sample period of 15 years (1996-2010) of gridded numerical data from the National Centers for Environmental Prediction (NCEP) Climate Forecast System Reanalysis (CFSR), and to a 20-yr dataset (1996-2015) of actual rawinsondes for the La Plata basin, reveals the benefits of revising the criteria. The modified criteria allow for the characterization of a wider spectrum of LLJs over key regions of South America, such as over the BolivianParaguayan border, Sierras de Córdoba in Argentina, and southern-southeastern Brazil. This wider range of events includes elevated LLJs, mostly with strong zonal components, that account for approximately $20 \%$ of the full sample of LLJs identified in the rawinsonde dataset investigated here. The revised criteria have the advantage of retaining the identification of episodes that meet the consecrated definition of the South American LLJ, while at the same time providing an augmented sample of such wind systems. Our results provide further insights into the forcing mechanisms of distinct types of LLJs in South America, ranging from topographic to baroclinic effects.
\end{abstract}

\section{Introduction}

A low-level jet (LLJ) is an airstream whose vertical profile displays a wind speed maximum in the lower troposphere. More than one atmospheric mechanism is known to generate LLJs (e.g., Stensrud 1996; Shapiro et al. 2016), with the implication that an LLJ can manifest itself in different ways. A first general class of LLJ results from the diurnal cycle of coupling and decoupling of the surface layer from the boundary layer above leading to an inertial oscillation that produces a nighttime wind maximum within the planetary boundary layer (PBL) (Blackadar 1957). Another PBL mechanism known to create nocturnal LLJs is the thermal wind balance response to diurnal variations in the horizontal temperature

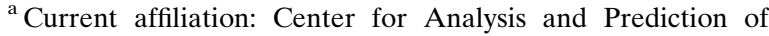
Storms, and School of Meteorology, University of Oklahoma, Norman, Oklahoma.
}

Corresponding author: Maurício I. Oliveira, mauricio.meteorologia@ gmail.com gradient produced by a sloping terrain (Holton 1967). ${ }^{1}$ These two mechanisms can work together in the generation of nocturnal LLJs (Garratt 1985; Jiang et al. 2007; Parish and Oolman 2010; Du and Rotunno 2014; Shapiro et al. 2016; Gebauer et al. 2017).

A second class of LLJ is mostly modulated by tight horizontal pressure gradients associated with synopticscale migratory disturbances and by the establishment of transverse ageostrophic circulations induced by upperlevel jet streams (Hoecker 1963; Browning and Pardoe 1973; Uccellini 1980; Markowski and Richardson 2010). The synoptically forced LLJ is usually termed "lowlevel jet stream" (Stensrud 1996) and tends to display a wind speed maximum at higher levels (up to $3000 \mathrm{~m}$ AGL) (Uccellini 1980; Liu et al. 2014; Du et al. 2014)

\footnotetext{
${ }^{1}$ Parish (2017) discusses a similar thermal-wind-related mechanism for the summertime LLJ in the U.S. Great Plains, which is more closely tied to seasonal changes in the horizontal pressure gradient just above the jet level owing to heating of the sloped terrain to the west.
} 
when compared to the PBL-induced LLJs. In any case, both classes of LLJs fit the more general concept of a lower-tropospheric jet-type wind maximum.

LLJs are relevant components of the global atmospheric system because in several regions they are responsible for transporting heat and water vapor poleward into the extratropics (Stensrud 1996; Marengo et al. 2004; Vera et al. 2006). In subtropical South America, the north-northwesterly LLJ often observed east of the Andes mountain range, and referred to as the South American low-level jet (SALLJ) (Vera et al. 2006), plays a crucial role in the hydrological cycle of the La Plata basin and surrounding areas (Berri and Inzunza 1993; Salio et al. 2002, hereafter SNS02; Marengo et al. 2004; M. G. Nascimento et al. 2016). The SALLJ is a component of the environment that leads to deep convection in the La Plata basin since it sets up a moist, unstable environment and promotes low-level lifting at its exit region or as it impinges on the Andes foothills and Sierras de Córdoba (Salio et al. 2007; Rasmussen and Houze 2011; Rasmussen et al. 2014; Rasmussen and Houze 2016). In addition, the SALLJ enhances the lower-tropospheric vertical wind shear (Rasmussen and Houze 2011), which is an important ingredient for the development of severe deep convection (Doswell 1991). Figure 1 shows the topographic map of subtropical and midlatitude South America indicating terrain elevation and main geographical features mentioned in this study.

A common approach to identify LLJs is through algorithms that detect low-level maxima in wind profiles (Bonner 1968; Whiteman et al. 1997; Saulo et al. 2000; Marengo et al. 2004). In the study for the U.S. Great Plains, Bonner (1968) proposed a set of criteria to identify the LLJ in the first $1500 \mathrm{~m}$ of the atmosphere utilizing rawinsonde data. In ascending order of strictness, Bonner's criteria 1, 2, and 3 require that the wind speed at the maximum level to be in excess of 12,16 , and $20 \mathrm{~m} \mathrm{~s}^{-1}$, respectively, and it must decrease by at least 6 , 8 , and $10 \mathrm{~m} \mathrm{~s}^{-1}$, respectively, to the next higher minimum or to $3 \mathrm{~km} \mathrm{AGL}$, whichever is lower.

Over the last decades, a large body of work addressing the SALLJ relied upon Bonner's less stringent criterion [i.e., the one utilizing the lower threshold of $12 \mathrm{~m} \mathrm{~s}^{-1}$ for the maximum wind speed, hereafter referred to as Bonner criterion 1 (BC1)] to detect the LLJ. One variant of the original $\mathrm{BC} 1$ was proposed by Nicolini and Saulo (2000) and slightly modified by SNSO2 to detect a special subset of the SALLJ that exhibits a pronounced southward penetration, known as the Chaco jet. The criteria employed by SNS02 were as follows: (i) the maximum wind speed must exceed $12 \mathrm{~m} \mathrm{~s}^{-1}$ at $850 \mathrm{hPa}$, while at the same time characterizing a flow originating in tropical latitudes and reaching at least $25^{\circ} \mathrm{S}$, (ii) the

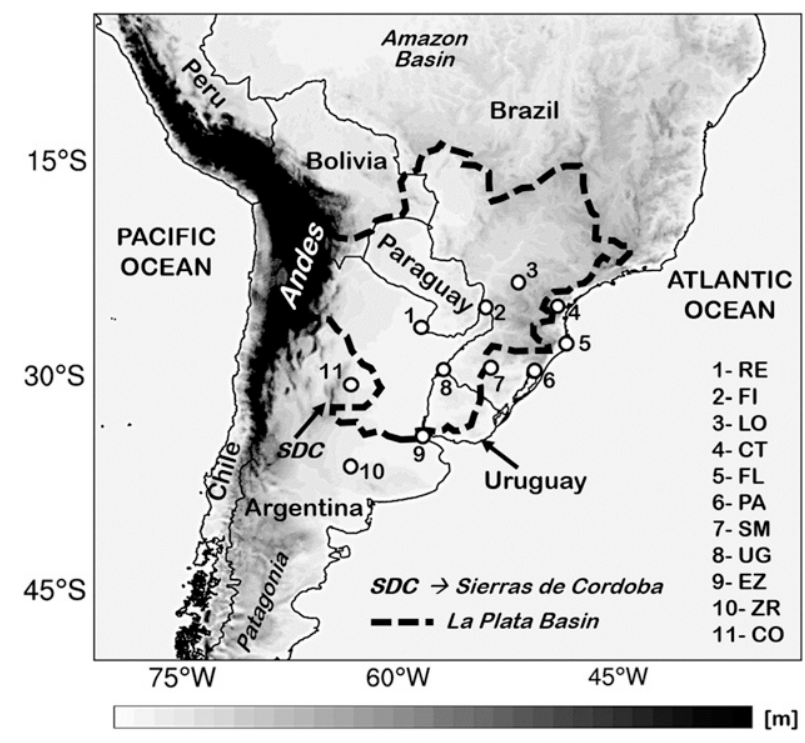

03006009001200150018002100240027003000

FIG. 1. Geographical map showing countries and terrain elevation in South America, and highlighting key regions mentioned in the text, such as the La Plata basin (enclosed by a thick dashed line), and Sierras de Córdoba. White numbered circles inform the geographical distribution of upper air stations from which wind profiles are analyzed in this study. See Table 1 for station acronyms.

vertical bulk difference between the $850-$ and $700-\mathrm{hPa}$ winds must be at least $6 \mathrm{~m} \mathrm{~s}^{-1}$ in the area enclosed by the $12 \mathrm{~m} \mathrm{~s}^{-1}$ isotach, and (iii) the meridional component must be southward and greater than the zonal component over the entire area enclosed by the $12 \mathrm{~m} \mathrm{~s}^{-1}$ isotach. Several climatological studies have used SNS02-type criteria to detect the SALLJ, which have contributed to the current state of knowledge of its relevance to the South American climate (SNS02; Marengo et al. 2004; Weykamp and Ambrizzi 2006; Salio et al. 2007; Saulo et al. 2007; M. G. Nascimento et al. 2016; and others).

However, in studying severe convective storms in southern Brazil (e.g., Nascimento et al. 2014), we have come across situations in which SNS02-based criteria, and even the original $\mathrm{BC} 1$ criteria, fail to detect events where the wind profile displays a clear-cut LLJ. This is particularly true for LLJs occurring in the eastern portion of the La Plata basin, and for situations involving a lowlevel jet stream. We argue that this happens because (i) the $\mathrm{BC} 1$ criteria, while well suited for detecting PBLrelated LLJs, are not particularly appropriate to characterize LLJs that are more elevated as is often the case with the low-level jet stream; ${ }^{2}$ and (ii) SNS02 assigns fixed

\footnotetext{
${ }^{2}$ The studies by Marengo et al. (2002) and Nicolini et al. (2004), specifically addressing the SALLJ, also have shown that this LLJ can display a core above $1500 \mathrm{~m}$, being as high as $3000 \mathrm{~m}$.
} 
pressure levels to inspect for wind speed extrema, and also intentionally excludes LLJs displaying strong zonal component. In fact, nowhere in SNSO2 is it stated that their approach would be suitable for the identification of LLJs in the entire South American continent; their focus was in a specific type of meridionally oriented LLJ closely associated with the moisture transport from the Amazon basin to the La Plata basin. Other studies that followed the SNS02 approach, such as Marengo et al. (2004) and M. G. Nascimento et al. (2016), also limited their attention to the identification of LLJs within the geographical domain of the SALLJ. Having said that, we show below that relevant information regarding LLJs in South America is missed if one applies the SNS02 approach to a larger domain of South America. In doing so we find that even for the SALLJ region, SNSO2 criteria do miss a nonnegligible number of LLJs. In addition, employment of the original $\mathrm{BC} 1$ approach does not suffice to provide a more general picture of LLJs in South America, especially for the northerly events.

In this study, modifications to the aforementioned criteria are proposed to allow for the inclusion of the characterization of more elevated forms of LLJs and zonally oriented LLJs, without deleterious implications to the identification of PBL-related LLJs and the different forms of the SALLJ. This is shown through a sensitivity analysis of LLJ detection upon the choice of the criteria applied for gridded numerical data from the National Centers for Environmental Prediction (NCEP) Climate Forecast System Reanalysis (CFSR) (Saha et al. 2010) for a sample period of 15 years (1996-2010), and for a 20-yr dataset (1996-2015) of actual rawinsondes for the La Plata basin (E. L. Nascimento et al. 2016).

Emphasis is placed on the identification of northerly LLJs in this investigation because of their key role in the meridional transport of warm moist air to the La Plata basin and in the regional severe weather context. However, the sensitivity analysis is also performed for (the less investigated) southerly LLJs. Although the main scope of this study is on the LLJ detection issue, some insights on the forcing mechanisms of LLJs in South America are also gained.

\section{Limitations in the traditional LLJ identification criteria}

To illustrate the limitations in the $\mathrm{BC} 1$ and $\mathrm{SNS} 02$ criteria to detect some important events of LLJs in South America, we discuss two examples that are representative of wind profiles that exhibit a well-defined LLJ, but that would not be flagged as such if $\mathrm{BC} 1$ and/or SNS02 criteria were utilized.

Figure 2a displays a wind profile extracted from CFSR valid at 0000 UTC 22 July 2010 for the grid point nearest
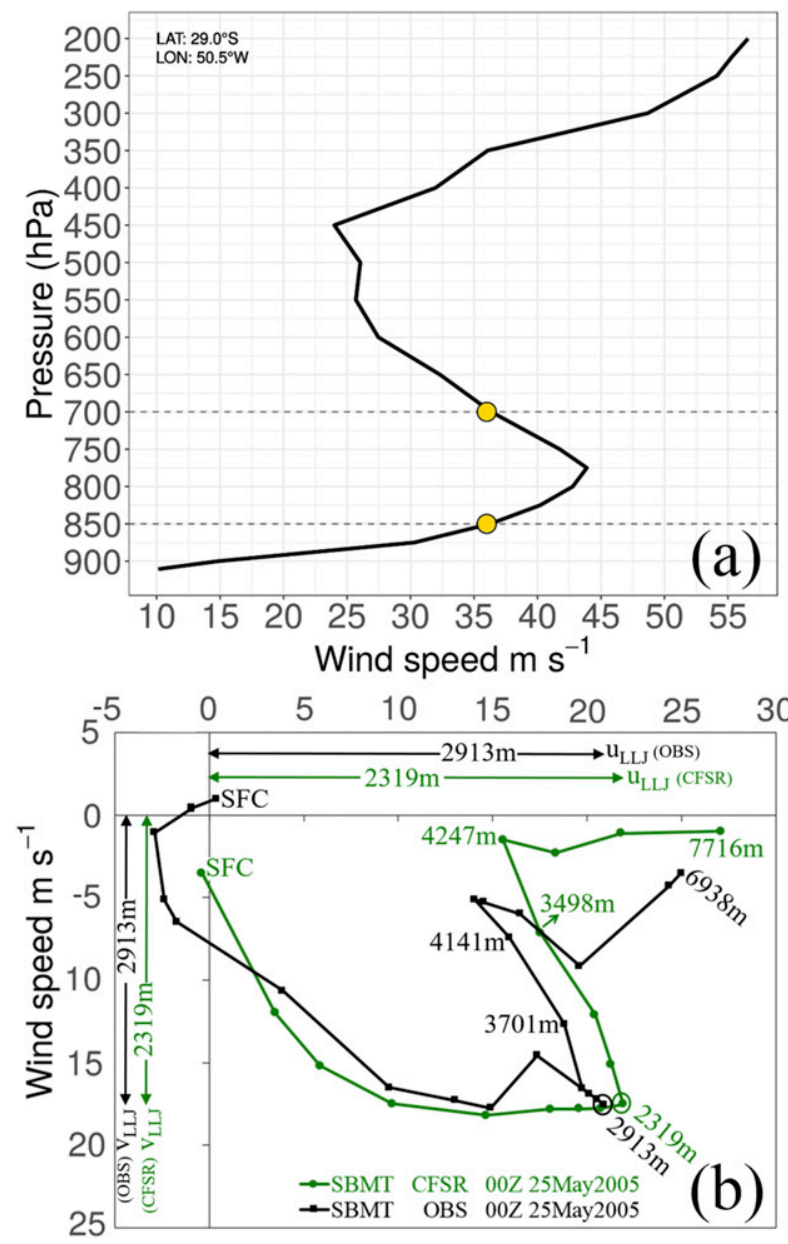

FIG. 2. Instances when criteria traditionally used to identify LLJs in South America fail to detect an LLJ. (a) Vertical wind profile extracted from CFSR at 0000 UTC 22 Jul 2010 for the grid point located at $29.0^{\circ} \mathrm{S}, 50.5^{\circ} \mathrm{W}$ in southern Brazil; yellow circles highlight the wind magnitude at the 850 - and $700-\mathrm{hPa}$ levels. (b) Environmental hodographs valid at 0000 UTC 25 May 2005 obtained from São Paulo's operational rawinsonde station in southeastern Brazil (SBMT; in black) and from CFSR's grid point nearest to SBMT (in green) [adapted from Fig. 15d of Nascimento et al. (2014)]; winds are in $\mathrm{m} \mathrm{s}^{-1}$; selected AGL heights are labeled (SFC = surface), and the heights of the LLJ are indicated as open circles.

the town of Canela located in the highlands of southern Brazil $\left(29.0^{\circ} \mathrm{S}, 50.5^{\circ} \mathrm{W} ; 837 \mathrm{~m}\right.$ above sea level) for an atmospheric environment that preceded a severe convective storm. The profile is plotted from model surface up to $200 \mathrm{hPa}$, utilizing all (above ground) tropospheric pressure levels available from CFSR. In a preliminary visual inspection, this wind profile depicts an LLJ-like structure with a $44 \mathrm{~m} \mathrm{~s}^{-1}$ wind maximum located at $775 \mathrm{hPa}$. When applying the original $\mathrm{BC} 1$ criteria the presence of an LLJ is confirmed; in contrast, when following SNS02 approach, no LLJ is detected. This happens because the vertical bulk difference between the 
850 - and $700-\mathrm{hPa}$ winds is near $0 \mathrm{~m} \mathrm{~s}^{-1}$, as highlighted by the yellow circles in Fig. 2a. It is worth mentioning that when the SNS02 criteria were established, global reanalysis data with finer vertical resolution were not available.

A second example is described with Fig. $2 b$ that shows the observed (black contour) and CFSR-generated (green contour) environmental hodographs valid at 0000 UTC 25 May 2005 for the city of São Paulo in southeastern Brazil $\left(23.5^{\circ} \mathrm{S}, 46.6^{\circ} \mathrm{W} ; 722 \mathrm{~m}\right.$ above sea level) for a synoptic environment in which an F3 tornado developed (Nascimento et al. 2014). Both hodographs display strong vertical wind shear and counterclockwise curvature in the lower troposphere. A northwesterly wind maximum is evident just below $3000 \mathrm{~m}$ AGL followed by a sharp weakening in the wind speeds aloft, before strong upper-level westerlies take place. For this profile neither $\mathrm{BC} 1$ nor SNS02 criteria detect an LLJ. This is because the wind maximum is rather high, such that a bulk wind difference of $6 \mathrm{~m} \mathrm{~s}^{-1}$ is not characterized if the search for a minimum wind speed aloft is limited to the $700-\mathrm{hPa}$ level (as in SNS02) or stopped at $3000 \mathrm{~m}$ (as in BC1). Moreover, this case exemplifies a situation where the zonal component of the wind maximum (indicated as $u_{\mathrm{LLJ}}$ in Fig. $2 \mathrm{~b}$ ) is greater than the respective meridional component $\left(v_{\mathrm{LLJ}}\right)$, which is intentionally excluded in the SNSO2 approach.

\section{Revised criteria for detecting LLJs in South America}

The situations discussed above are not rare in subtropical South America east of the Andes, especially for regions located farther east in the continent, as southern Brazil. Hence, a revision in the set of criteria for detecting LLJs in observations and gridded output for South America is desirable. These revised criteria should comprise the detection of a wider spectrum of LLJ flows while keeping the traditional and consecrated notion of the SALLJ as an important subset of LLJs in South America. Below we propose a set of criteria that keeps all essential features of the $\mathrm{BC} 1$ approach, yet aimed at including more elevated LLJs.

For a given low-level wind profile to be considered an LLJ, the following modified $\mathrm{BC} 1$ criteria must be met simultaneously:

- Winds must display a local maximum in speed within the lowest $3000 \mathrm{~m} \mathrm{AGL}$ and the maximum must be equal to or greater than $12 \mathrm{~m} \mathrm{~s}^{-1}$.

- The wind speed must decrease by at least $6 \mathrm{~m} \mathrm{~s}^{-1}$ from the maximum speed to the first minimum found aloft or to the speed at $4000 \mathrm{~m}$ AGL, whichever occurs first.

The modifications to $\mathrm{BC} 1$ include the following: (i) extending to $1500 \mathrm{~m}$ the depth of the layer employed to search for the wind maximum of the LLJ (viz., surface to $1500 \mathrm{~m}$ to surface to $3000 \mathrm{~m}$ ); and (ii) extending from 3000 to $4000 \mathrm{~m}$ AGL the top of the layer to search for the wind minimum aloft. Modification (i), or similar to (i), is also found in other LLJ studies such as Arritt et al. (1997), Whiteman et al. (1997), and Chen and Tomassini (2015), but the addition of modification (ii) is not explicitly mentioned in any of those studies. In defining an index for detecting nocturnal LLJs around the world, Rife et al. (2010) utilized winds at $4000 \mathrm{~m}$ AGL as representative of the wind minimum aloft, but their study limited the investigation to PBL-related LLJs found at $500 \mathrm{~m}$ AGL. Modification (ii) is an important addition if the objective is to detect a wider range of LLJ features that include fairly high LLJs as the one exemplified in Fig. 2b.

Notice that in our modified criteria [OliveiraNascimento-Kannenberg (ONK18)] no requirement is imposed for the magnitude of the meridional component of the wind maximum being larger than its zonal counterpart, which is one of the aspects that strongly deviates from the SNSO2 approach. As with $\mathrm{BC} 1$, the above criteria permit the identification of southerly LLJs as well. In this study LLJs from the north, defined as any LLJ displaying negative meridional wind components, are analyzed separately from the southerly ones. In the case of LLJs displaying exactly zero meridional components the choice was made to classify them as northerly LLJs. Because these represent less than $6 \%$ of the total number of LLJs identified in this study, classifying them as southerly LLJs would not lead to any significant change in our results. For the southerly LLJs the sensitivity analysis is performed utilizing only $\mathrm{BC} 1$ and ONK18 because, by conception, the SNS02 method was not elaborated for the detection of southerly LLJs.

Finally, some additional considerations to the criteria proposed above are needed to address two particular situations. First, when double-core or multicore LLJs are found, the strongest one is considered to be the nose of the LLJ. Second, on occasions when the magnitude of the wind maxima persists for consecutive vertical levels (or is repeated in nonconsecutive levels) the lowest level is considered the height of the LLJ.

In the next section we discuss the results from the application of the ONK18 approach to CFSR data and wind profiles obtained from rawinsondes. It is important to stress that the sample periods analyzed here serve adequately to explore the LLJ detection issue, but do not provide a complete climatology of the LLJ for South America, which is not the scope of this study. Seasonal analyses are carried out as referred to the austral hemisphere, with fall being from March to May, winter from June to August, spring from September to November, and summer from December to February. 

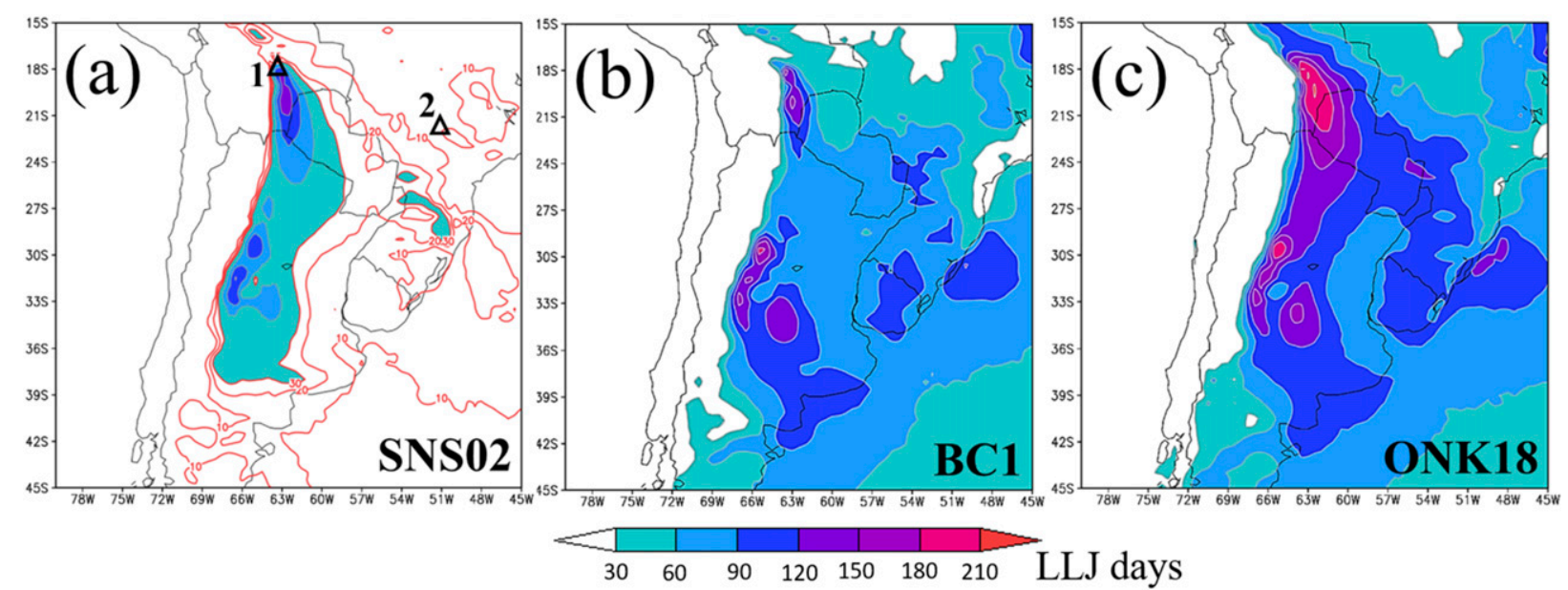

FIG. 3. Mean annual number of days with a northerly LLJ for the 1996-2010 period based on CFSR data for subtropical and midlatitude South America considering the three distinct sets of criteria for LLJ detection: (a) SNS02, (b) BC1, and (c) the revised criteria proposed in this study (ONK18). Color shading starts at $30 \mathrm{LLJ}$ days, and varies at intervals of 30 days. In (a) the red solid contours are the isopleths of 10 and 20 LLJ days for SNS02. The numbered triangles in (a) display the two locations for the plots shown in Figs. 4 and 8.

\section{Application of the revised criteria}

a. CFSR wind profiles

\section{1) ANNUAl Distribution}

To compare the distinct sets of criteria (viz., SNS02, $\mathrm{BC} 1$, and $\mathrm{ONK} 18$ ) and illustrate the benefits of the revised criteria for LLJ detection, we first determine the average number of days per year with LLJ occurrence for the 15 -yr period from 1996 to 2010 using gridded model data from CFSR with $0.5^{\circ} \times 0.5^{\circ}$ latitude-longitude grid spacing over a domain covering subtropical South America. The 1996-2010 period is chosen because of the availability of quality-assured rawinsonde data for the $\mathrm{La}$ Plata basin during this same period (E. L. Nascimento et al. 2016), allowing a general assessment of some of the CFSR-based results compared to the observations.

CFSR provides wind variables for 27 tropospheric pressure levels from 1000 to $100 \mathrm{hPa}$ but, for every grid point, only pressure levels above the model surface are utilized. In addition, grid points with model surface above the $850 \mathrm{hPa}$ level are ignored. To count as an "LLJ day" an LLJ must be characterized in at least one of the 6-hourly output available from CFSR for that day.

Figure 3a shows the results for northerly LLJs employing the SNS02 approach, with the color shading indicating areas with at least $30 \mathrm{LLJ}$ days per year for the 1996-2010 period, and red contours enclosing areas below that threshold (viz., 10 and 20 LLJ days per year). Maximum occurrences, surpassing 120 LLJ days, are found along the eastern foothills of the Andes over the Bolivian-Paraguayan border (centered around $19^{\circ} \mathrm{S}$, $63^{\circ} \mathrm{W}$ ) and over west-central Argentina. The maximum over southern Bolivia is in good agreement with the results found in SNS02 and several other studies for summertime LLJs in South America. However, the second maximum, over western Argentina, was not mentioned in SNS02. This disagreement possibly results from distinct model horizontal and vertical grid spacing, since SNS02 utilized gridded data from the European Centre for Medium-Range Weather Forecasts reanalysis (ERA) available at that time. As discussed in Saulo et al. (2004), the western Argentinean sector highlighted in Fig. 3a is also known for the association between LLJs and the topographically induced northwestern Argentinean low (NAL) (Seluchi et al. 2003).

In applying the $\mathrm{BC} 1$ criteria (Fig. $3 \mathrm{~b}$ ) the same two sectors of maximum occurrences persist, but the areas of 30-90 LLJ days extend eastward covering the entire La Plata basin and the southwestern Atlantic basin. For SNS02, this enlarged area is only found for values below 30 LLJ days (red contours in Fig. 3a). With BC1 another region of maximum LLJ activity, above 120 LLJ days, becomes apparent in central Argentina, near the Sierras de Córdoba (see Fig. 1 for location). These findings indicate that northerly LLJs can be more common over the La Plata basin and surrounding coastal areas than suggested by previous studies that limited their attention to the traditional definition of the SALLJ and to the foothills of the Andes. The study by Rife et al. (2010), who investigated the global distribution of shallow diurnally varying LLJs employing a global mesoscale reanalysis system, also found LLJ activity extending toward the eastern portion of the La Plata basin, with one important maximum around the Sierras de Córdoba during the austral summer (see their Fig. 4b). However, their 

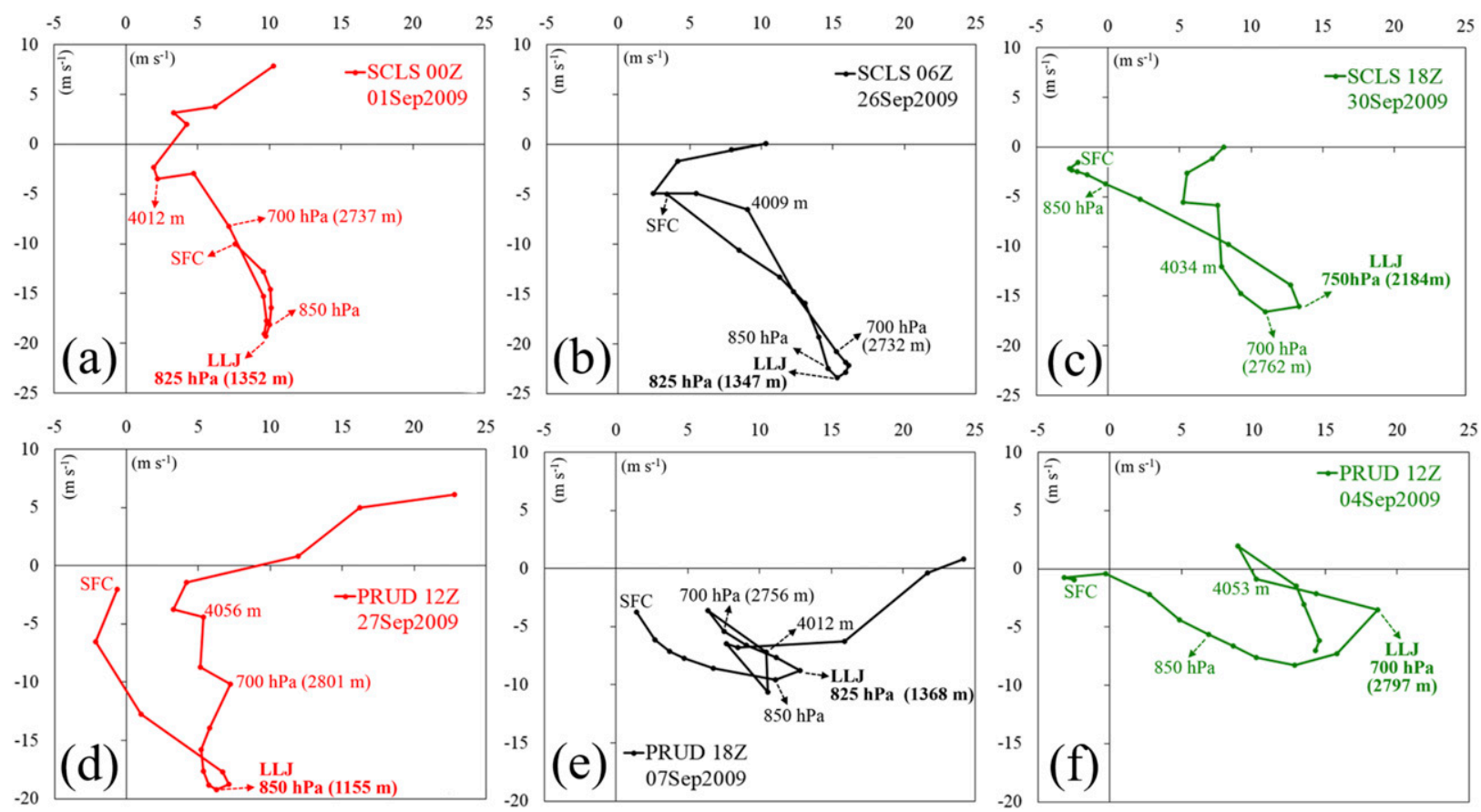

FIG. 4. Environmental hodographs extracted from CFSR (from model surface to approximately $8 \mathrm{~km}$ AGL) for selected LLJ events during the month of September 2009. (a)-(c) Hodographs for the grid point located at $18.0^{\circ} \mathrm{S}, 63.0^{\circ} \mathrm{W}$ [Santa Cruz de la Sierra (SCLS); triangle 1 in Fig. 3a]. (d)-(f) Hodographs for the grid point located at $22.5^{\circ} \mathrm{S}, 51.5^{\circ} \mathrm{W}$ [Presidente Prudente (PRUD); triangle 2 in Fig. $3 \mathrm{a}$ ]. Times and dates are indicated inside each panel; labels indicate selected AGL heights and pressure levels, as well as LLJ heights.

LLJ detection index was limited to PBL-related LLJs at $500 \mathrm{~m}$ AGL; some important discrepancies between our results and those by Rife et al. (2010) will be shown later.

When the ONK18 criteria are applied (Fig. 3c), the general area of LLJ occurrence does not change much compared to the results from the $\mathrm{BC} 1$ criteria, but the average number of LLJ days does increase. The elongated maximum following the eastern foothills of the Andes experiences a substantial enhancement, particularly over the Bolivian-Paraguayan border where it exceeds 180 LLJ days per year. This is a particularly relevant result because this area is one of the key regions for the SALLJ activity (e.g., Marengo et al. 2004). Also interesting is the appearance of a secondary maximum in LLJ activity off the coast of Brazil near $30^{\circ} \mathrm{S}$. This northerly LLJ is embedded in the western branch of the South Atlantic high in a region where strong sea surface temperature gradients usually reside (e.g., Acevedo et al. 2010). To our knowledge, such a feature coasting the southern Brazilian shore has not been documented in the literature, except, perhaps, for Rife et al. (2010), but only during summer.

The main factor explaining the differences in LLJ days between BC1 (Fig. 3b) and ONK18 (Fig. 3c) is the depth of the layer in which LLJs are searched for. Hence, the choice in ONK18 for including LLJs that are more elevated has a clear impact on the characterization of LLJ occurrence in South America. To better highlight the aspects that explain the above results, we analyze Fig. 4, which compares environmental hodographs for the month of September 2009 extracted from CFSR for two grid points (indicated by black triangles in Fig. 3a): one located close to Santa Cruz de la Sierra (SCLS), in south-central Bolivia, and another one located near Presidente Prudente (PRUD) in São Paulo state, southeastern Brazil. For both locations, the hodographs in red indicate wind profiles that were characterized as LLJs by all three sets of criteria; hodographs in black are profiles flagged as LLJs by BC1 and ONK18 criteria, but not by $\mathrm{SNSO2}$ criteria; hodographs in green are profiles indicated as LLJs only by ONK18 criteria.

The comparison of Figs. 4a and 4b, for SCLS, shows that the SNS02 approach fails to identify an LLJ if the wind profile is such that the 850 - and $700-\mathrm{hPa}$ winds do not depart significantly from each other. Furthermore, in the case of more elevated LLJs, both SNSO2 and BC1 criteria miss the event, as exemplified for SCLS in Fig. 4c for a case when the nose of the LLJ is above $2000 \mathrm{~m}$ AGL. Figure 4d exhibits a wind profile from PRUD that contains an LLJ according to all criteria. This is because the LLJ is below $1500 \mathrm{~m}$ AGL and displays a strong northerly component. In the case shown in Fig. 4e a double-core LLJ is in place in PRUD and is detected by 


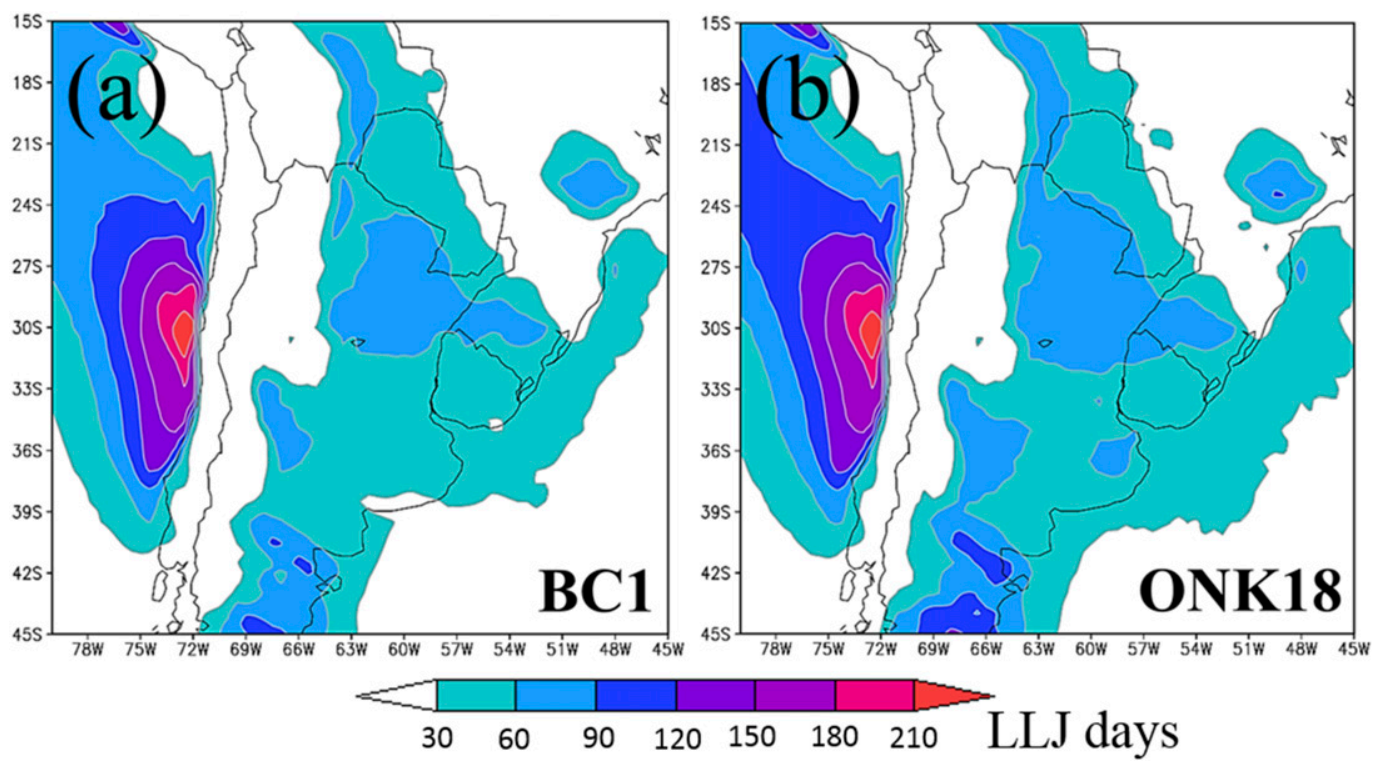

FIG. 5. As in Fig. 3, but for southerly LLJs. Only results from (a) BC1 and (b) ONK18 are shown.

both $\mathrm{BC} 1$ and $\mathrm{ONK} 18$ at $1368 \mathrm{~m} \mathrm{AGL}$; but it displays a zonal component that is greater than the meridional component and, thus, it is discarded by the SNS02 criteria. Finally, Fig. $4 \mathrm{f}$ shows an elevated LLJ, with its nose above $2700 \mathrm{~m}$, and with a strong westerly component; only the ONK18 criteria detect this prefrontal LLJ.

In contrast with the northerly LLJs, differences between $\mathrm{BC} 1$ and ONK18 in the maps of southerly LLJ days are subtle (Fig. 5), with just a slight tendency to an increased number of events when utilizing ONK18. The most frequent occurrence is along the central coast of Chile (around $30^{\circ} \mathrm{S}, 74^{\circ} \mathrm{W}$ ). This is in good agreement with results from Garreaud and Muñoz (2005) and Muñoz and Garreaud (2005) who have studied the southerly coastal jet observed atop the marine boundary layer off the shore of that country, and also with findings from Rife et al. (2010). Over the La Plata basin, a rather broad region of 60-90 LLJ days is present over northern Argentina, extreme southern Brazil, and along the Andes foothills of south-central Bolivia. Based on enhanced observations made available in 1999 during the Large-Scale BiosphereAtmosphere Experiment-TRMM campaign, Marengo et al. (2002) also identified the occurrence of southerly LLJs in central Bolivia associated with relatively cold and dry surges, being less frequent than the northerly LLJs.

Farther east, over southeastern Brazil (centered around $23^{\circ} \mathrm{S}, 49^{\circ} \mathrm{W}$ ), a localized maximum of southerly LLJs is also found. Interestingly, there is observational evidence of the frequent occurrence of a shallow nocturnal southeasterly LLJ in a localized region within this area over the state of São Paulo (e.g., Pereira et al.
1995), being mostly related to a combination of topographic effects and inertial oscillation. Despite the good agreement regarding location, determining whether the CFSR-based wind profiles detect this specific LLJ system is beyond the scope of this study. Another region east of the Andes displaying a relative maximum in southerly LLJs is southern Patagonia, south of $39^{\circ} \mathrm{S}$. Some of these Patagonian LLJs are produced during cold air surges associated with migratory baroclinic systems traversing the southern Andes (not shown), which is an association that deserves a more detailed investigation.

The lack of a significant difference between $\mathrm{BC} 1$ and ONK18 regarding the number of days with southerly LLJs (Fig. 5) does not necessarily imply that elevated southerly LLJs are rare in the CFSR-based profiles for South America. What it does indicate is that it is difficult to find days when the only southerly LLJ found after inspecting the four synoptic times is an elevated one, being in contrast with the result found for northerly LLJs (Fig. 3). The comparison between $\mathrm{BC} 1$ and ONK18 criteria also display very slight distinctions for southerly LLJs when analyzing the sensitivity of detection differences with respect to season and time of the day. For this reason, the seasonal and diurnal variabilities discussed below are limited to the northerly LLJs.

\section{2) SEAsonal VARIAbiLity of THE DETECTION OF NORTHERLY LLJS}

To verify if seasonality influences the degree of distinction among SNS02, BC1, and ONK18 approaches, we examine Fig. 6, which compares the average number 

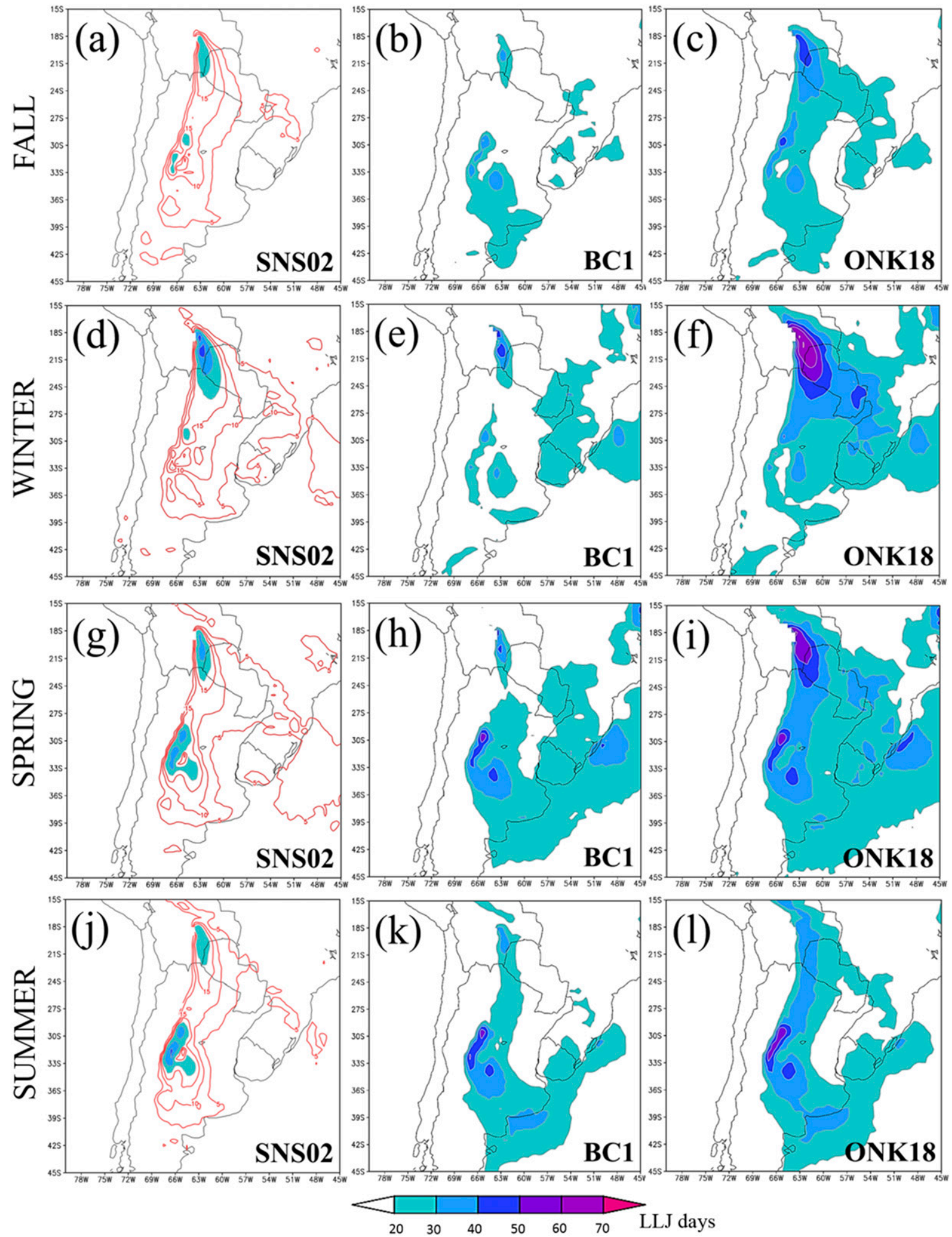

FIG. 6. As in Fig. 3, but for the mean number of days with a northerly LLJ per season: (a)-(c) fall, (d)-(f) winter, (g)-(i) spring, and (j)-(l) summer. (left) SNS02, (middle) BC1, and (right) ONK18. Color shading starts at 20 LLJ days, and varies at intervals of 10 days. For SNS02, the red solid contours are the isopleths of 5, 10, and 15 LLJ days. 
of northerly LLJ days per season obtained from the three sets of criteria for the 1996-2010 period. In all panels the color shading indicates areas with more than 20 LLJ days per season, while the red contours in the SNS02 panels show areas with 5-20 LLJ days per season. Overall, the same general finding described for the annual distribution of LLJ days is repeated for all seasons separately; namely, an eastward and southeastward extension of the area with more frequent LLJ activity (i.e., above 20 LLJ days) accompanied by an increase in the number of LLJ days when one changes from SNS02 to BC1 approaches (cf. the first two columns of Fig. 6 for all seasons). Differences between these two approaches are particularly interesting during the warm season (Figs. 6g,h vs 6j,k) as regions in southern Brazil, including coastal areas, and around Bahía Blanca $\left(39^{\circ} \mathrm{S}\right.$, $60^{\circ} \mathrm{W}$ ) and Sierras de Córdoba in Argentina exhibit maxima in LLJ activity (above 30 LLJ days) not shown in the corresponding SNSO2 maps.

It is shown above that a considerable number of LLJs detected in the Bolivian-Paraguayan border are elevated (cf. Figs. 3b and 3c). By contrasting $\mathrm{BC} 1$ and ONK18 in Fig. 6 one finds that this result is particularly true for winter, which is the season of highest frequency of LLJ days for that sector according to all three approaches analyzed. ${ }^{3}$ Moreover, the result from the ONK18 approach shows an important relative maximum in LLJ days over the Argentina-Brazil-Paraguay triple border region (centered approximately around $25^{\circ} \mathrm{S}, 55^{\circ} \mathrm{W}$ ) in winter and spring (Figs. $6 \mathrm{f}$ and $6 \mathrm{i}$, respectively) that is not clear in the $\mathrm{BC} 1$ map. Interestingly, the study by Rife et al. (2010), limited to shallower LLJs, does not indicate such maximum during winter either.

The line contours in the panels of the first column of Fig. 6 indicate that the SNS02 criteria do not miss all LLJ events in eastern La Plata basin, but lead to a considerable lower number of LLJ days. Best described by ONK18 than by both SNS02 and BC1 approaches is the transition from lower latitudes in winter (Fig. 6f) to higher latitudes in summer (Fig. 61) of the maximum LLJ activity, which follows the similar seasonal march of baroclinicity observed in subtropical South America

\footnotetext{
${ }^{3}$ The finding that winter is the season with most frequent (northerly) LLJ days in the Bolivia-Paraguay sector is also in agreement with results described in the climatology by Montini et al. (2016) who utilized CFSR data. Marengo et al. (2004), employing NCEP-NCAR Reanalysis I data (Kalnay et al. 1996), found a similar result for northern Paraguay (town of Mariscal Estigarribia; approximately $22.0^{\circ} \mathrm{S}, 60.6^{\circ} \mathrm{W}$ ) but not for central Bolivia (city of SCLS; approximately $17.8^{\circ} \mathrm{S}, 63.2^{\circ} \mathrm{W}$ ) where LLJs were found to be more frequent during the warm season.
}

(e.g., Garreaud 2000). This result points to the role played by synoptic-scale mechanisms associated with migratory baroclinic systems in driving the more elevated forms of the northerly LLJ in South America (Saulo et al. 2004). This finding is also consistent with the seasonal variation within the La Plata basin of the atmospheric conditions favorable for severe convective storms, as discussed, for example, in E. L. Nascimento et al. (2016).

\section{3) DiURnal VARIABILITY OF THE DETECTION OF NORTHERLY LLJS}

The CFSR-based diurnal variability of the northerly LLJs according to the three approaches is analyzed with the aid of Fig. 7. At 0000 and 0600 UTC (first and second rows in Fig. 7), all three methods detect the hotspots for northerly LLJs in the Bolivian-Paraguayan border and Sierras de Córdoba. However, both areal coverage and number of LLJ days increase from SNS02 to BC1. From $\mathrm{BC} 1$ to $\mathrm{ONK} 18$ the increase in area, although present, is not as drastic, but the number of LLJ days is considerably higher, especially at 0600 UTC in lower latitudes and along the eastern foothills of the Andes (Figs. 7e,f). In both $\mathrm{BC} 1$ and $\mathrm{ONK} 18$ the maritime areas of LLJ activity in the South Atlantic become more evident. SNS02 criteria are also capable of capturing LLJs in the eastern La Plata basin and even portions of the South Atlantic, particularly at 0600 and 1200 UTC (see red contours), but the number of LLJ days is much lower than the informed by $\mathrm{BC} 1$ and ONK18. Overall, apart from 1800 UTC, the three methods indicate a zone of enhanced LLJ occurrence related to the SALLJ, which then extends into central and coastal Argentina, with another branch stretching along Paraguay into southern Brazil. All three approaches indicate that 0600 UTC is the most active period of northerly LLJs within the diurnal cycle for most of the La Plata basin (being just slightly more active at 0000 UTC in the SALLJ region). In all situations, the number of LLJ days is higher for ONK18.

During afternoon hours (1800 UTC), LLJ activity is reduced over the entire domain (Figs. 7j-1), consistent with increased vertical mixing in the PBL. SNS02 and BC1 display a small spot of +30 LLJ days in southcentral Bolivia, while ONK18 indicates a much larger area and higher number of LLJ days. Compared to BC1 this characterizes a rather frequent presence of elevated LLJs in spite of a deeper PBL. Elsewhere, at 1800 UTC, $\mathrm{BC} 1$ shows more LLJ days in the oceanic area near the coast of southern Brazil compared to SNS02, without differing much from ONK18 in that sector.

To further investigate the diurnal cycle of northerly LLJs in South America, we evaluate the diurnal 

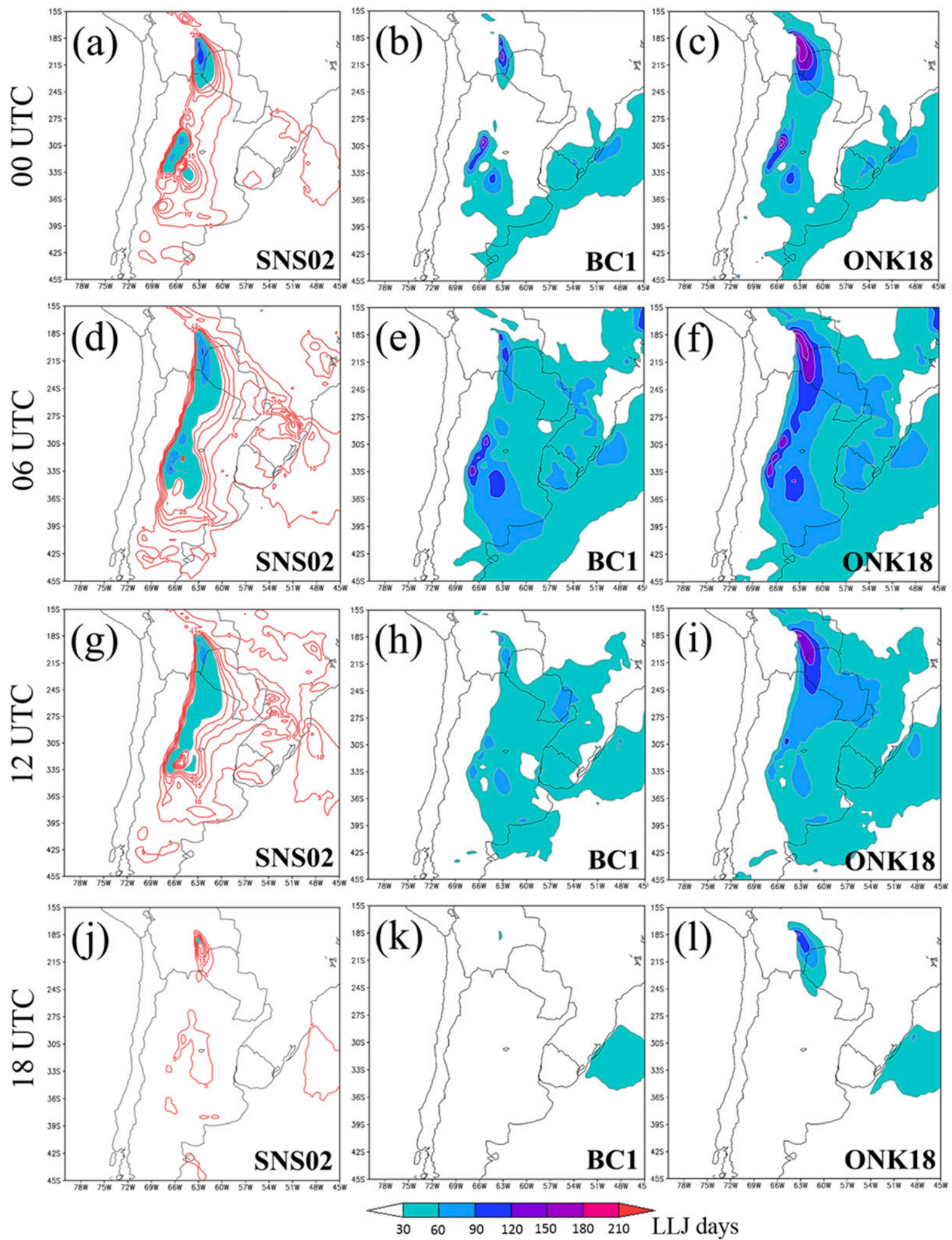

FIG. 7. As in Fig. 3, but for the mean annual number of northerly LLJ occurrences per synoptic time: (a)-(c) 0000 UTC, (d)-(f) 0600 UTC, (g)-(i) 1200 UTC, and (j)-(l) 1800 UTC. (left) SNS02, (middle) BC1, and (right) ONK18. Color shading starts at 30 LLJ days, and varies at intervals of 30 days. For SNS02, the red solid contours are isopleths from 5 to 25 LLJ days in intervals of 5 days. 

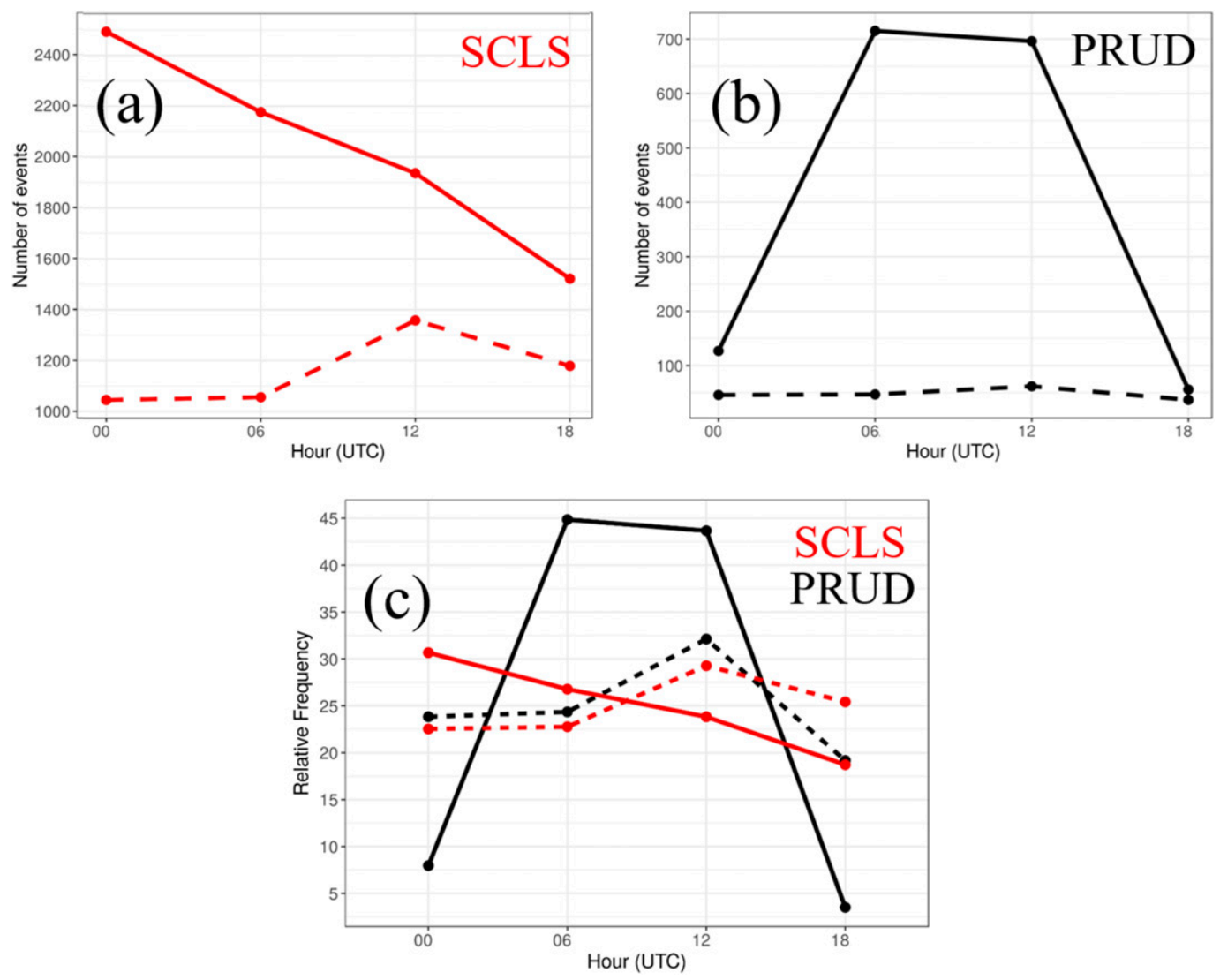

FIG. 8. (a) The 6-hourly time series (from 0000 to 1800 UTC) of the number of northerly LLJs detected by the ONK18 approach applied to CFSR data from 1996 to 2010 for the grid point located at $18.0^{\circ} \mathrm{S}, 63.0^{\circ} \mathrm{W}$ (SCLS; triangle 1 in Fig. 3a); solid line is for the full northerly LLJ sample, while dashed line is for the elevated northerly LLJ sample. (b) As in (a), but for the grid point located at $22.5^{\circ} \mathrm{S}, 51.5^{\circ} \mathrm{W}$ (PRUD; triangle 2 in Fig. 3a). (c) As in (a) and (b), but for the relative frequency of LLJ detection per sample.

variation of elevated LLJs (i.e., the ones above $1500 \mathrm{~m}$ AGL) as compared to the total sample of northerly LLJs for two regions: SCLS and PRUD (see again Fig. 3a for geographical location). The results shown refer only to the ONK18 criteria. For SCLS (Fig. 8a), the full sample of northerly LLJs (solid line) displays a more frequent activity at 0000 UTC, decreasing almost linearly until 1800 UTC. Conversely, the full sample of LLJs at PRUD (solid line in Fig. 8b) indicates a far more common LLJ detection at 0600 and 1200 UTC. In both locations the diurnal cycle of the elevated LLJs (dashed lines) is apparently much weaker relative to the full samples, especially at PRUD. In addition, as expected, the LLJ samples at 1800 UTC for both places are largely dominated by elevated cases, this being particularly true for PRUD.

Given the distinct sizes between full and elevated-only samples, a better assessment of the diurnal variability is provided in Fig. 8c, which shows the frequencies of LLJ detection with respect to each corresponding sample. Again, the diurnal cycle of elevated northerly LLJs at
PRUD (black dashed line) is remarkably weaker than the one found for the full sample (black solid line). In addition, the relative amplitude of the diurnal cycle in PRUD is larger than in SCLS, which may help to explain the persistent spot of LLJ activity in the SALLJ region throughout the day (third column of Fig. 7). In SCLS the diurnal cycle of the elevated cases is also weaker compared to the respective cycle of the total LLJ occurrence, but not for a large margin. This suggests that the elevated LLJs in the SALLJ region are more affected by diurnal variations in vertical mixing within the PBL than in locations farther east in the La Plata basin.

\section{b. Wind profiles from actual rawinsondes}

Given vertical resolution issues associated with model gridded data, the analysis of any modified criteria for detecting LLJs also should include their application to wind profiles obtained from actual upper-air observations. Only the BC1 and ONK18 criteria are considered in this analysis because the SNS02 approach was not 
TABLE 1. List of operational rawinsonde stations from the La Plata basin utilized in this study. The period of study is January 1996December 2015.

\begin{tabular}{lcccrc}
\hline \hline Rawinsonde station & $\begin{array}{c}\text { Abbreviation in } \\
\text { this study }\end{array}$ & ICAO code & Location & Elevation (m) & $\begin{array}{c}\text { Sample size } \\
\text { (No. of profiles) }\end{array}$ \\
\hline Córdoba & CO & SACO & $31.3^{\circ} \mathrm{S}, 64.2^{\circ} \mathrm{W}$ & 474 & 4922 \\
Curitiba & CT & SBCT & $25.5^{\circ} \mathrm{S}, 49.2^{\circ} \mathrm{W}$ & 908 & 8492 \\
Ezeiza/Buenos Aires & EZ & SAEZ & $34.8^{\circ} \mathrm{S}, 58.5^{\circ} \mathrm{W}$ & 20 & 7629 \\
Florianópolis & FL & SBFL & $27.6^{\circ} \mathrm{S}, 48.5^{\circ} \mathrm{W}$ & 5 & 6650 \\
Foz do Iguaçu & FI & SBFI & $25.5^{\circ} \mathrm{S}, 54.6^{\circ} \mathrm{W}$ & 180 & 7534 \\
Londrina & LO & SBLO & $23.3^{\circ} \mathrm{S}, 51.3^{\circ} \mathrm{W}$ & 569 & 4936 \\
Porto Alegre & PA & SBPA & $30.0^{\circ} \mathrm{S}, 51.2^{\circ} \mathrm{W}$ & 3 & 9923 \\
Resistência & RE & SARE & $27.5^{\circ} \mathrm{S}, 59.0^{\circ} \mathrm{W}$ & 52 & 4688 \\
Santa Maria & SM & SBSM & $29.7^{\circ} \mathrm{S}, 53.7^{\circ} \mathrm{W}$ & 85 & 5408 \\
Santa Rosa & ZR & SAZR & $36.6^{\circ} \mathrm{S}, 64.2^{\circ} \mathrm{W}$ & 20 & 5418 \\
Uruguaiana & UG & SBUG & $29.8^{\circ} \mathrm{S}, 57.0^{\circ} \mathrm{W}$ & 74 & 4237 \\
\hline
\end{tabular}

conceived for application to actual rawinsonde data. Both northerly and southerly LLJs are investigated. The data source is the same one utilized by E. L. Nascimento et al. (2016), and includes 0000 UTC (2100 LST) and 1200 UTC (0900 LST) soundings from the upper-air observation network in the La Plata basin, comprising a period of 20 years, from 1 January 1996 to 31 December 2015. Table 1 lists the upper-air stations utilized in this study as well as the sample size of wind profiles for each station, ${ }^{4}$ and Fig. 1 provides their geographical distribution. A total number of 69837 wind profiles were analyzed, which corresponds to $43 \%$ of the total number of profiles that would have been available had soundings been performed twice a day for every single day of operation of the stations in the aforementioned period.

Our sample of wind profiles is not evenly distributed among 0000 and 1200 UTC. Approximately $66 \%$ of the profiles refer to the 1200 UTC time (with profiles from the Argentinean upper-air stations being particularly scarce at 0000 UTC), which, according to the analysis conducted with the CFSR data (Fig. 7), is still inside the diurnal period of active northerly LLJ activity in the eastern La Plata basin, yet missing the 0600 UTC maximum. Therefore, the results presented below do not offer a comprehensive view of the climatology of LLJs, but they provide relevant information addressing the LLJ detection subject.

\section{1) ANNUAL AND SEASONAL DISTRIBUTION}

A total of 7032 (3968) northerly (southerly) LLJs were found utilizing ONK18 criteria, representing 10.1\%

\footnotetext{
${ }^{4}$ The sample sizes in Table 1 are larger than those informed by E. L. Nascimento et al. (2016) because that study required a deeper layer with wind data, whereas for the present study quality-assured data were needed only for the lowest $4000 \mathrm{~m}$ AGL increasing the effective number of available profiles.
}

$(5.7 \%)$ of the total sample. Figure 9a shows the percentage frequencies of wind profiles of our sample that are identified as northerly LLJs after employing BC1 criteria (black numbers) and ONK18 criteria (colored numbers). For both sets of criteria, stations located in the most inland portion of the La Plata basin, namely, ZR, CO, $\mathrm{RE}$, and FI, are the ones with most frequent occurrence of LLJs. RE is the station with highest frequency, consistent with the fact that is the one closest to the climatological position of the SALLJ exit (e.g., SNS02).

As found for the CFSR data (Figs. $3 b$ and $3 c$ ), an increase in the relative frequency of LLJs was evident for all stations when changing from BC1 to ONK18 (Fig. 9a). In particular, a rather substantial increase in LLJ frequency was found for $\mathrm{CO}$ in central Argentina, which is a region where the interaction between the LLJ and local topography is instrumental for convective initiation (Romatschke and Houze 2010; Rasmussen and Houze 2011, 2016; Rasmussen et al. 2014; Repinaldo et al. 2015).

For southerly LLJs (Fig. 9b), an increase in frequency is found when comparing results from $\mathrm{BC} 1$ and ONK18, albeit lesser than the respective increase obtained for northerly LLJs. This result confirms that the apparent lack of sensitivity of southerly LLJ frequency upon the choice of criteria described for CFSR can be explained by the fact that it is rare to find days when an elevated LLJ is the only LLJ present, whereas when analyzing individual wind profiles elevated southerly LLJs are not unusual, although considerably less frequent than the northerly counterparts. Another interesting feature in Fig. 9b is the lower frequencies of southerly LLJs for stations on the northernnortheastern portion of the analyzed domain, regardless of the criteria utilized. A similar result was found with CFSR profiles, just south of the local maximum of southerly LLJs in southeastern Brazil mentioned earlier (see Fig. 5).

Figure 10 displays the percentage frequency of profiles with northerly LLJs for the four seasons (for the 

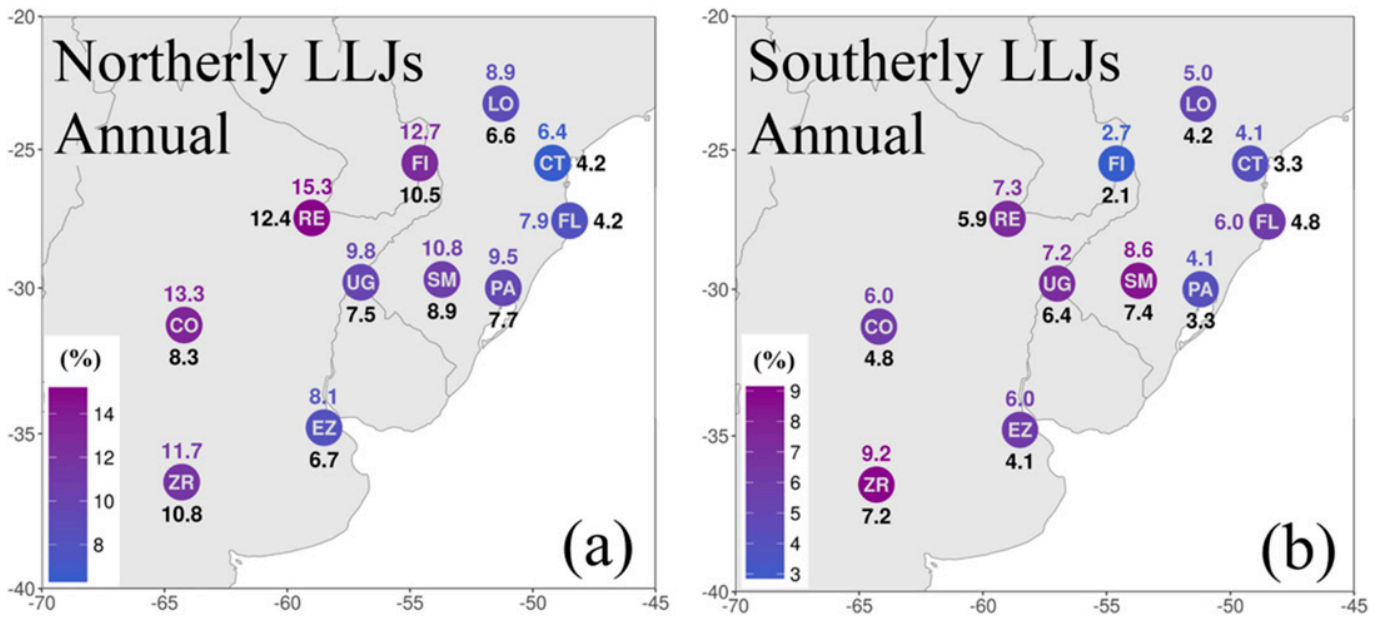

FIG. 9. (a) Percentage frequency of wind profiles from La Plata basin's upper-air observation network that were identified as northerly LLJs based on BC1 criteria (black numbers) and ONK18 criteria (colored numbers varying according to the percentage values; see inset for color convention) for the 1996-2015 period. (b) As in (a), but for southerly LLJs. Note the different color scales used in (a) and (b). See text for information on acronyms and sample sizes for each site.

sake of brevity, we do not discuss the seasonal distribution of southerly LLJ detection). The annual distribution described in Fig. 9a for northerly LLJs is replicated during spring (Fig. 10a), but with higher frequencies in all stations for both BC1 and ONK18 approaches indicating an active springtime activity of northerly LLJs. For summer (Fig. 10b), all stations display frequencies below the corresponding annual values. The one exception is the southernmost station of ZR for which summer virtually ties with spring as the season with most frequent LLJ detection for both $\mathrm{BC} 1$ and ONK18 criteria. A similar result is found for CFSR profiles in the sector around the ZR region (see Fig. 6 , around $36^{\circ} \mathrm{S}, 64^{\circ} \mathrm{W}$ ).

During fall (Fig. 10c), LLJ frequency at ZR experiences a decrease considering $\mathrm{BC} 1$ and ONK18 approaches, while in southern Brazil and in the remaining stations in Argentina the frequencies display either a slight drop or roughly the same value compared to summer, not characterizing a significant change. The exceptions are UG and CO, where LLJ detection is more often in fall than in summer for the ONK18 approach. For winter, perhaps the most interesting result is the high percentage frequencies observed for stations RE and FI (Fig. 10d) in the same general region where the ONK18 criteria applied to CFSR data highlighted a relative maximum in LLJ detection (Fig. 6f), pointing to the robustness of this finding. Marengo et al. (2004), as well as Montini et al. (2016), already discussed the maximum in LLJ activity during winter for Paraguay, but the results with ONK18 criteria add the information that many of these northerly LLJs are more elevated given the considerable difference in frequencies between the $\mathrm{BC} 1$ and ONK18 approaches on both CFSR and observed wind profiles.

The wintertime increase in LLJ activity in southern Brazil is also confirmed by the observations (Fig. 10d), especially when compared to summer and fall. This result was not characterized in the study by Rife et al. (2010) on shallow nocturnal LLJs (cf. their Figs. 4a and 4b). For Argentina, LLJ frequencies at ZR are lowest in winter for both $\mathrm{BC} 1$ and $\mathrm{ONK} 18$, being consistent with the CFSR findings (i.e., with the main axis of LLJ activity moving northward in winter, away from ZR). At EZ and CO the observed enhancement in LLJ frequency in winter compared to fall (Fig. 10d) is not clearly replicated in the respective CFSR map of LLJ days (Fig. 6), but one should keep in mind the paucity of 0000 UTC soundings in Argentina. CO is the only station where the choice of the LLJ detection criteria implies a conflicting result regarding the trend in LLJ frequency among two consecutive seasons. This is observed from summer to fall; while $\mathrm{BC} 1$ indicates a slight drop in frequency (or comparable frequencies) ONK18 points to an increase in frequency, suggesting a distinction in the elevated LLJ regime during fall as compared to the BC1 LLJs, at least for the 1200 UTC time for which $\mathrm{CO}$ soundings are mostly available.

In general, despite sampling issues, the detection of northerly LLJs utilizing observed wind profiles reiterates the overall seasonal march over eastern La Plata basin found with CFSR, which consists of higher percentage frequencies of LLJs during winter and spring and lower frequencies during summer and fall. The amplitude of the seasonal variability is stronger when 

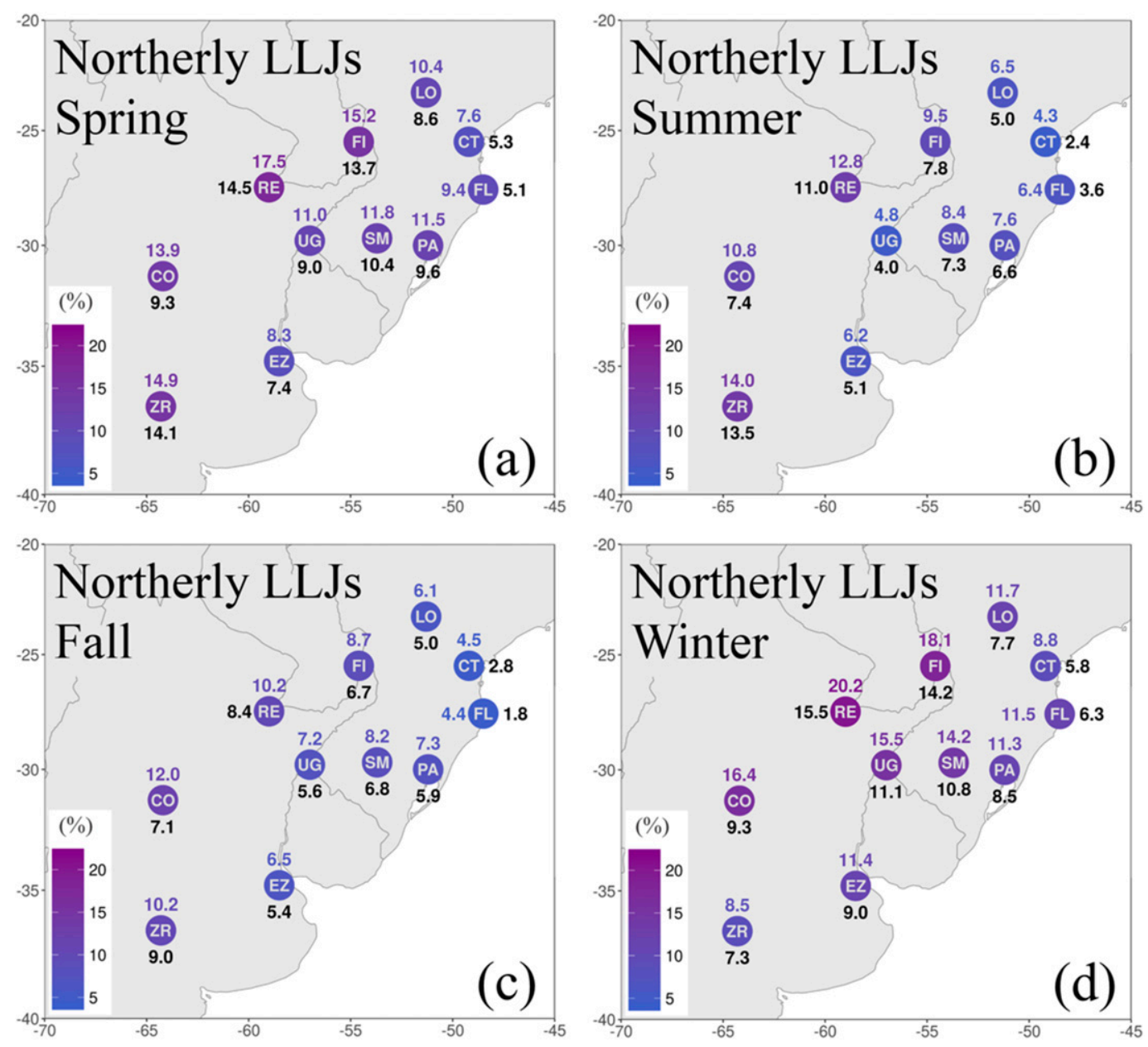

FIG. 10. As in Fig. 9a, but discriminated by season: (a) spring, (b) summer, (c) fall, and (d) winter.

elevated LLJs are included in the sample (Fig. 10). The site at highest latitude (ZR) is the notable exception to the seasonal march mentioned above, with LLJs being most (least) frequent during spring and summer (fall and winter). In summary, the results described with the rawinsonde dataset ratify the main findings discussed with the CFSR data regarding the LLJ detection issue.

\section{2) Additional Relevant aspects}

The histogram in Fig. 11 shows the distribution of all LLJ events detected in the 11 rawinsonde stations in the 1996-2015 period as a function of AGL height, for both northerly and southerly cases. Despite displaying a peak of LLJ occurrence within the 300-800 m AGL range [which is similar to the range reported in Whiteman et al. (1997) for the Great Plains of North America] the distribution reveals a broad spectrum of heights for the LLJs of both groups. It would be difficult to pick one single height as being representative of the core level of
LLJs. Even at the overall maximum, around $600 \mathrm{~m}$ AGL, the number of LLJs represent less than $15 \%$ of the total sample of each group (i.e., northerly and southerly LLJs). In turn, selecting a single pressure level allows for varying heights, but in a much narrower range than the one depicted in Fig. 11.

A considerable number of cases are observed above $1500 \mathrm{~m}$ AGL, representing situations that are not identified by the $\mathrm{BC} 1$ criteria. ${ }^{5}$ For the northerly LLJs a number of 1572 , or $22.4 \%$ of the sample of this group, displayed a core above $1500 \mathrm{~m}$ AGL. Similarly, 782 southerly LLJs were elevated, which is $19.7 \%$ of the respective sample. Hence, in situ observations, albeit

\footnotetext{
${ }^{5}$ It is important to clarify that in our approach if a double core $\mathrm{LLJ}$ is in place and its respective lower core satisfies the $\mathrm{BC} 1 \mathrm{cri}-$ teria, then the lower core does count as a hit for $\mathrm{BC} 1$ even if the higher core is above $1500 \mathrm{~m}$, which, in turn, counts as the only hit for ONK18.
} 


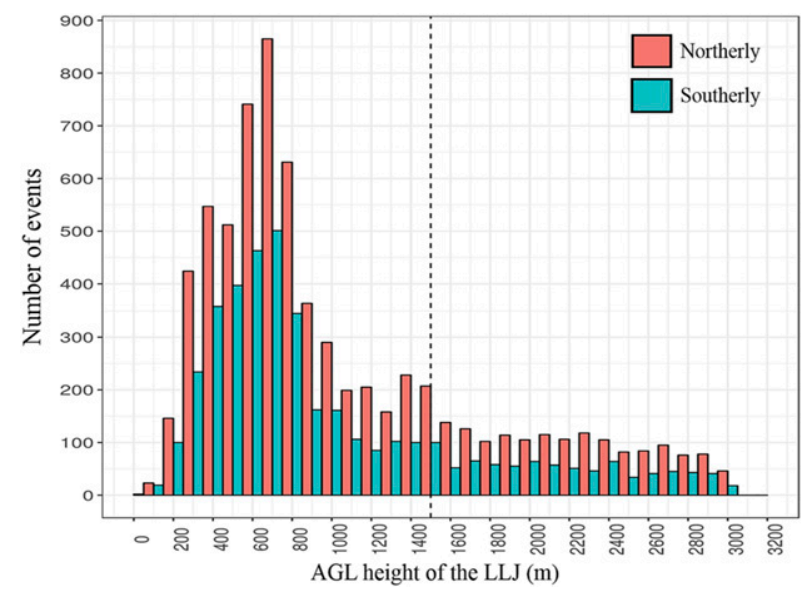

FIG. 11. Histograms of the number of northerly and southerly LLJ events detected with the rawinsonde data as a function of height (in class intervals of $100 \mathrm{~m}$ AGL) at the jet core. The vertical dashed line marks the $1500 \mathrm{~m}$ AGL height.

limited, also indicate that the more elevated form of LLJ is not a rare occurrence in the La Plata basin.

Naturally, the 1500-m height threshold employed to discriminate the elevated LLJs within the full sample of LLJs is an arbitrary choice. In this study, the 1500-m threshold is primarily motivated by the goal of investigating the information that is lost if the traditional choice for height threshold proposed by Bonner (1968) is utilized in the La Plata basin. Nevertheless, it is interesting to note the quasi-steady nature of the tail in the distribution precisely above $1500 \mathrm{~m}$ for both groups of LLJs in Fig. 11, in a layer that is roughly within the 850- and 700-hPa pressure levels. Hence, in our sample the more elevated LLJs show even less of a propensity for a preferential height when compared to the shallower ones.

We must stress that the general distribution of LLJ heights shown in Fig. 11 is not representative of all rawinsonde sites. To illustrate that, Fig. 12 compares the relative frequencies of northerly LLJs by AGL height for SM and CO; the reader should refer to Table 1 for information regarding differences in sample sizes among these stations. While in SM the LLJ distribution per AGL height replicates the general one described in Fig. 11, in CO our sample shows no peak of LLJ activity at lower levels and the distribution extends throughout most of the range of heights being considered. In fact, in CO the elevated LLJs account for $39 \%$ of its respective sample, well above the $22.4 \%$ found when considering all stations. This is well reflected in terms of percentage frequencies in Fig. 9a where a considerable difference exists between $\mathrm{BC} 1$ and ONK18 for CO. Interestingly, for southerly LLJs (figure not shown) the broad distribution described above for CO disappears, with all stations displaying a general pattern of the type shown in

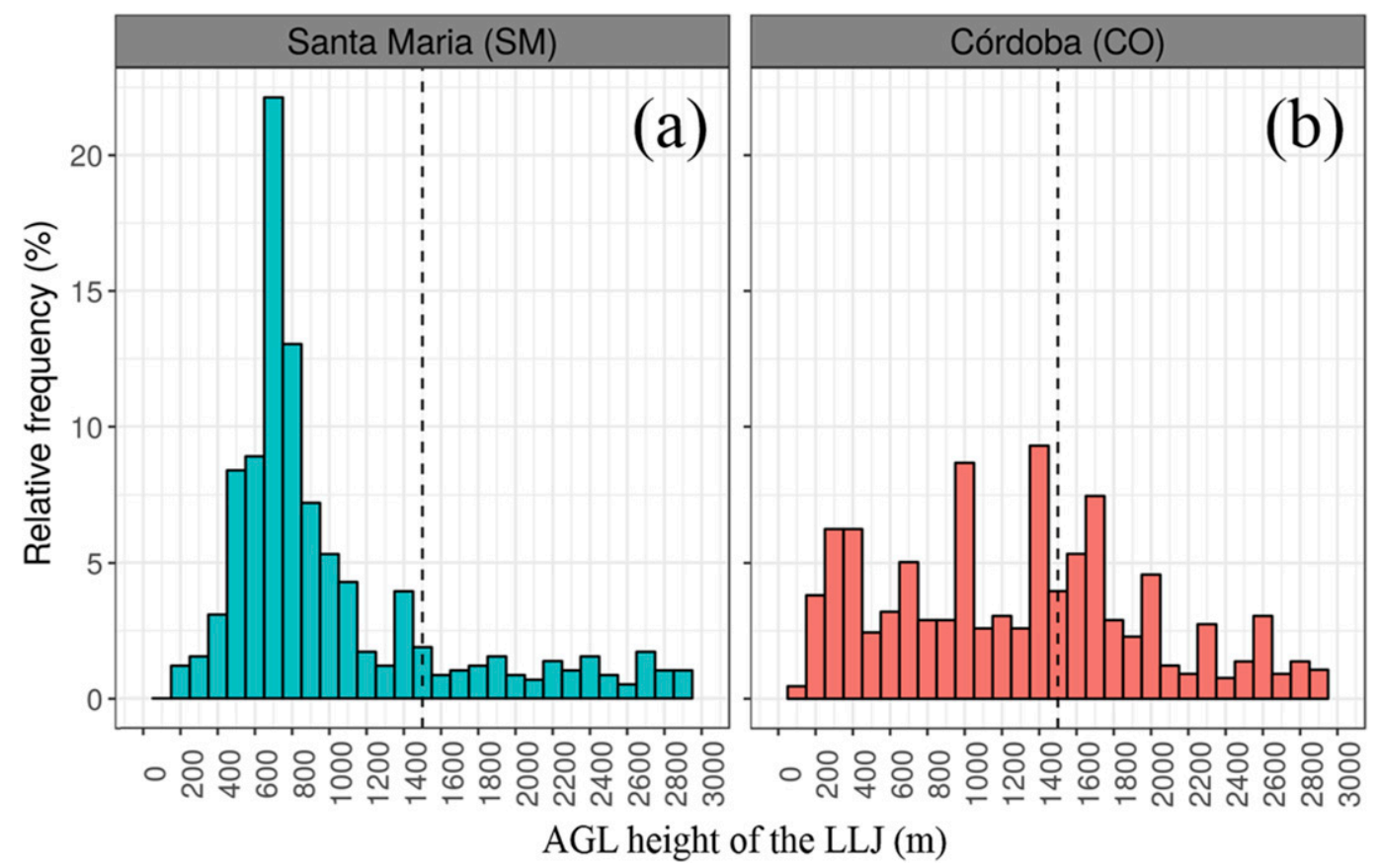

FIG. 12. Histograms of the relative frequency of northerly LLJs as a function of height of the jet core (in class intervals of $100 \mathrm{~m}$ AGL) for (a) Santa Maria (SM) and (b) Córdoba (CO). In both panels the vertical dashed line marks the $1500 \mathrm{~m}$ AGL height. 
Fig. 11. This aspect explains the better performance of the $\mathrm{BC} 1$ approach in detecting LLJs in the southerly regime when compared to the northerly one.

Despite the sampling issues in our dataset, the LLJ distribution for $\mathrm{CO}$ displayed in Fig. 12b highlights the severe limitation of commonly used criteria for LLJ detection in identifying what sometimes becomes a rather continuous spectrum of LLJs. In addition, the strong site-to-site variability found for the northerly events indicates that methods for the identification of LLJs that allow for the characterization of local idiosyncrasies in their behavior are desirable.

In terms of wind direction, the histogram in Fig. 13a informs the number of LLJ events at $5^{\circ}$ intervals varying from west on the far left to east on the far right of the panel. The histogram reveals an approximate bimodal distribution for the northerly LLJs in the eastern La Plata basin. The most frequent direction is centered right at the north, but an important secondary maximum appears on the east. The high frequency of easterly LLJs is mostly associated with the sites located in Rio Grande do Sul (RS) state in extreme southern Brazil (viz., PA, SM, and UG; see Fig. 1 for location), as exemplified in Fig. 14a for SM, which is in clear contrast with CO (Fig. 14b) where easterly LLJs are uncommon. Campos and Santos (2007) also found east as the most frequent direction of LLJs in Porto Alegre (PA) at 0000 UTC based on rawinsonde data from 1989 to 2003. For 1200 UTC they found north and west as the most frequent directions. Results from Rife et al. (2010) also indicated a strong easterly component for the shallow nocturnal LLJ during (austral) summer in extreme southern Brazil. This result suggests that local topography, consisting of a $50-\mathrm{km}$-wide zonally oriented depression that crosses most of central RS state, is an instrumental forcing mechanism of such LLJs from the east, combined with the climatological position of the South Atlantic subtropical high to the east of RS.

A very different picture of the wind direction with the northerly LLJs is revealed when only elevated jets are considered (Fig. 13b). In that case, the northwestern quadrant becomes the most important one in describing the direction of the LLJ. Figure $14 \mathrm{c}$ reveals a sharp change to the northwest of the most frequent wind direction in SM. This indicates that the frequent LLJs from the east described earlier are more restricted to the low levels, reinforcing the argument that they are mostly topographically induced. In CO the corresponding distribution for the elevated LLJs (Fig. 14d) is considerably less altered in comparison with its full sample distribution (Fig. 14b), becoming just slightly skewed toward the northwest.

Stations from southern Brazil (except for FL) and RE, in far northern Argentina, are the ones displaying the
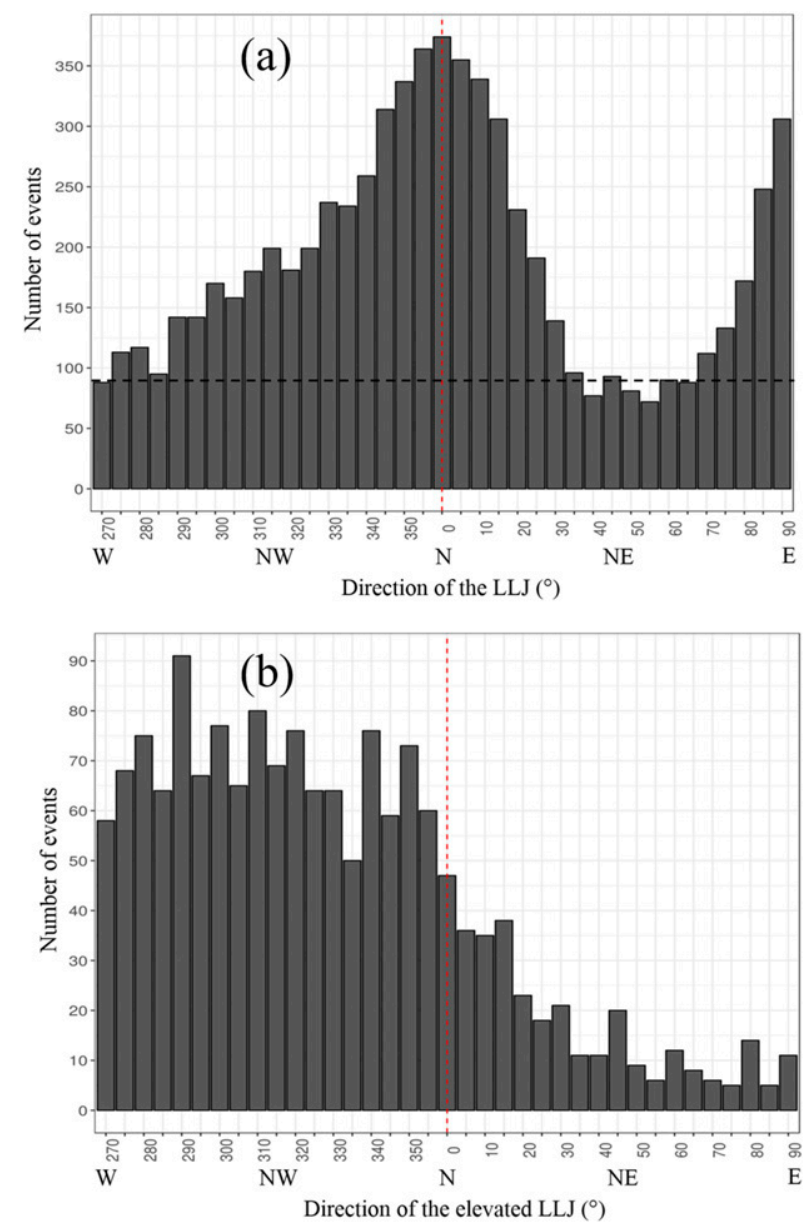

FIG. 13. Histograms of the number of northerly LLJ events detected with the rawinsonde data as a function of the wind direction at the jet core (in class intervals of $5^{\circ}$ ). (a) Total sample of northerly LLJs and (b) sample of elevated northerly LLJs only. (from left to right) The abscissas vary from west $\left(270^{\circ}\right)$ to east $\left(90^{\circ}\right)$, with the vertical dashed line in the center indicating north $\left(0^{\circ}\right)$. In (a) the horizontal dashed line represents the top of the vertical scale in (b).

most evident propensity for elevated LLJs from northwest (not shown). Most likely, this is related to synopticscale baroclinic systems that alter the lower-tropospheric winds in the La Plata basin by steering the northerly flow toward southern Brazil as low pressure systems migrate downstream (Vera et al. 2002; Campetella and Vera 2002). In such a development, the low-level flow acquires a more prominent northwesterly component. It also has been shown that northwesterly low-level flow is one common feature associated with environments conducive to very heavy rain and severe convective storms in southern Brazil (Teixeira and Satyamurty 2007; Nascimento et al. 2014; Oliveira et al. 2016; Sperling 2018).

As for southerly episodes, the histogram in Fig. 15a shows the distribution of all LLJs as a function of wind 


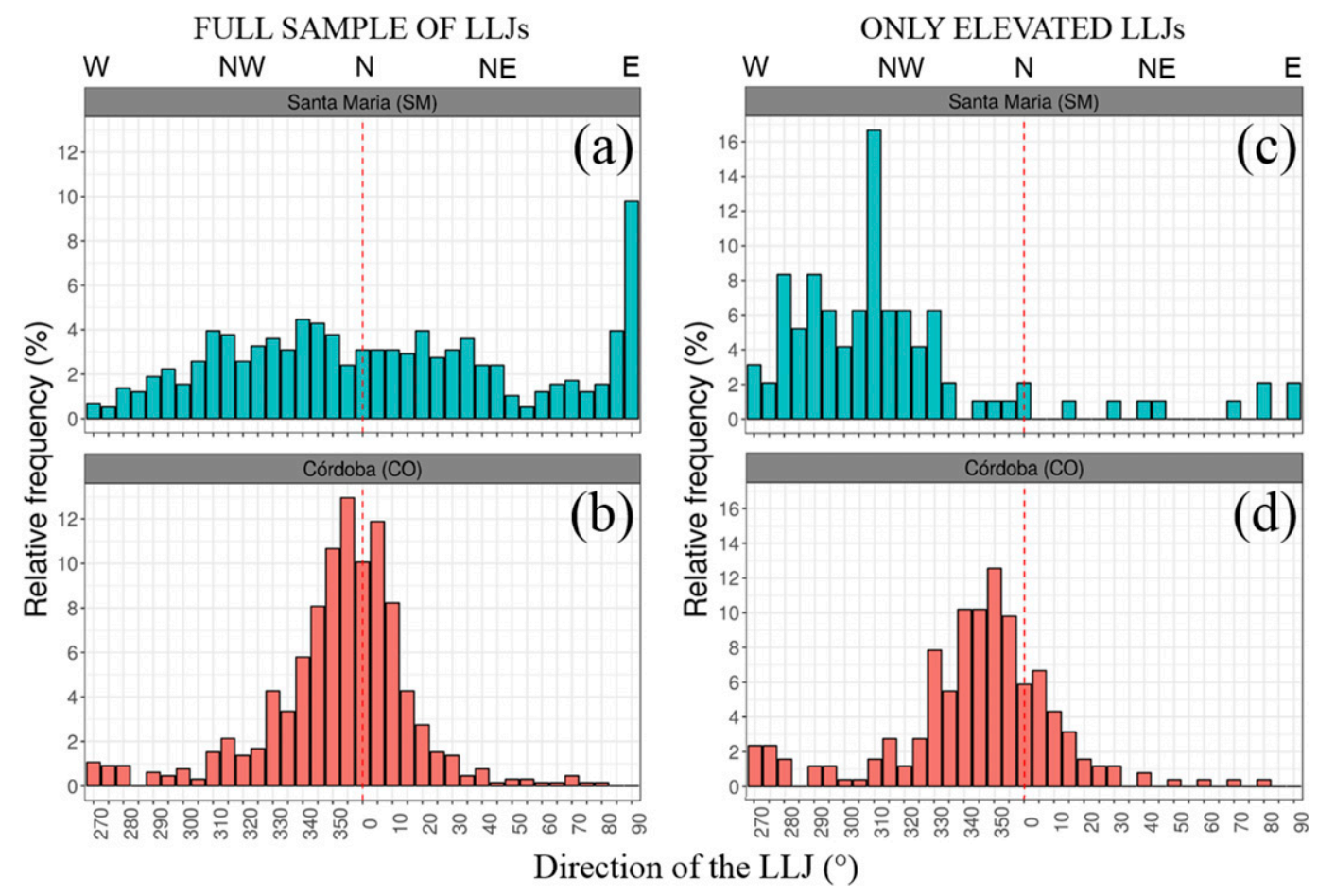

FIG. 14. As in Fig. 12, but for the relative frequency of northerly LLJs as a function of the wind direction at the jet core in class intervals of $5^{\circ}$, comparing (a),(c) Santa Maria (SM) with (b),(d) Cordoba (CO). Relative frequency with respect to the (left) full sample of northerly LLJs and (right) the sample of elevated northerly LLJs only. Notice the distinct vertical scales in the two columns.

direction, with south being indicated in the center of the abscissa. The low values informed at the very edges of the histogram [i.e., for $270^{\circ}(\mathrm{W})$ and $90^{\circ}(\mathrm{E})$ ] are an artifact of the choice for classifying as "northerly" the LLJs that are exactly from west or from east. Figure 15a indicates that a large number of the events that are flagged as a southerly LLJ in this study actually consist of easterly LLJs. Evidently this peak in occurrence consists of the same maximum in LLJ frequency described for the northerly LLJs. Thus, in combining Figs. 13a and 15a, it becomes clear that south is just the third most frequent direction of LLJs in the eastern La Plata basin if we consider the four main cardinal points.

Once again, stations in RS state (PA, SM, and UG) in extreme southern Brazil are the ones with most prominent peak occurrences of LLJs from the east. It is interesting that the CFSR wind profiles seem to capture this local pattern by keeping a narrow zonally oriented area of southerly LLJ days right over the central portion of RS state (along latitude $30^{\circ} \mathrm{S}$ in extreme southern Brazil) in Fig. 5. In CO the distribution displays the same Gaussian-like behavior found for the northerly LLJs (not shown), indicating that zonally oriented LLJs are quite uncommon in $\mathrm{CO}$, at least as observed from 1200 UTC soundings.
For elevated southerly LLJs again a much different distribution takes place (Fig. 15b). As discussed with the northerly sample, elevated LLJs from the east or southeast are much less common in the eastern La Plata basin, with west and southwest becoming the most frequent directions. In studying cold air intrusions in subtropical South America associated with migratory baroclinic systems, Garreaud (2000) showed that the mean 1000-850-hPa flow over the eastern La Plata basin at the peak of the intrusions (i.e., during the strongest winds) is south-southwesterly, especially during winter, when such intrusions often affect southern Brazil. Many of the elevated southwesterly LLJs indicated in Fig. 15b can be related to these cold air intrusions.

\section{Conclusions}

The need for a more expanded view of the LLJ occurrence in subtropical South America was the main motivation for this study. We have shown that wellestablished criteria utilized to identify LLJs in South America fail to detect an important number of situations when a well-defined LLJ is in place; this being particularly true for wind profiles containing an 

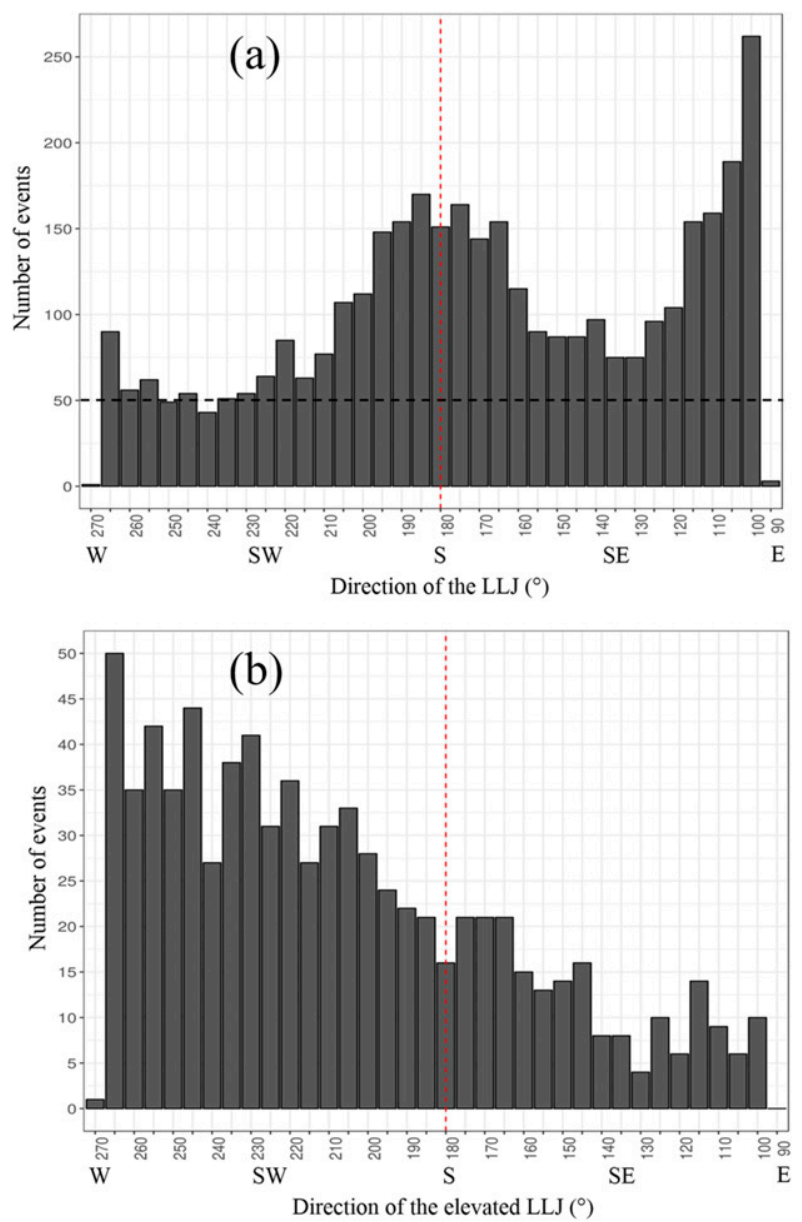

FIG. 15. As in Fig. 13, but for southerly LLJs. (a) Total sample of southerly LLJs and (b) sample of elevated southerly LLJs only. (from left to right) The abscissas vary from west $\left(270^{\circ}\right)$ to east $\left(90^{\circ}\right)$, with the vertical dashed line in the center indicating south $\left(180^{\circ}\right)$. In (a) the horizontal dashed line represents the top of the vertical sale in (b).

elevated LLJ. This shortcoming is either because the search for the LLJ profile is limited to too shallow a layer, or because of the requirement that the magnitude of the meridional component of the LLJ is larger than its zonal component, as has been traditionally employed to characterize the SALLJ.

The benefits obtained from slight changes to the criteria for LLJ identification in South America, namely, by deepening the layer for LLJ characterization and dropping the requirement of a relatively weak zonal component of the LLJ were analyzed. This analysis was performed by applying the revised set of criteria to both model gridded data and actual rawinsondes for the La Plata basin. The results showed that the revised criteria not only identify virtually all LLJ episodes detected by the traditional approaches, but also widen the spectrum of LLJs by including a number of wind profiles that display LLJs that are missed by the previous approaches. This finding includes LLJ events in key regions of South America such as over the BolivianParaguayan border, the Sierras de Córdoba in central Argentina, and in southern and southeastern Brazil. Most of the additional events detected by the employment of the revised criteria consist of elevated LLJs with a fairly strong zonal component, accounting for approximately $20 \%$ of the full sample of LLJs (for both southerly and northerly events).

Results from this study raise important issues regarding the lack of suitability of the original set of criteria proposed by Bonner (1968) for the characterization of the large spectrum of LLJs that are observed in South America, and maybe worldwide. In addition, we conclude that algorithms utilized for the detection of LLJs must not rely on the analysis of wind speeds in a single height or in a single pressure level, unless, perhaps, one is interested in studying a very specific type of LLJ, which must be clearly indicated. Significant variability was found from place to place regarding the heights of the LLJ cores; even at a single site, the height of the LLJ can vary considerably.

One key aspect not addressed in this study is the sensitivity of the LLJ detection to the speed criteria. As discussed in Whiteman et al. (1997), Campos and Santos (2007), and Montini et al. (2016), altering wind speed thresholds for the identification of the LLJ can lead to significant changes in the results. Hence, a more comprehensive approach to the LLJ detection issue should take into account both aspects (height and speed thresholds). In addition, several aspects discussed in this study are related to the more fundamental question of what exactly is an LLJ. As mentioned in the introduction section, a myriad of wind profiles may satisfy the general notion of an LLJ, and yet represent very distinct phenomena from a dynamic perspective.

Future studies must address the sensitivity of the climatology of LLJs in South America to the choice of LLJ criteria, as well as the weather patterns and forcing mechanisms that control the more elevated LLJs and the LLJs occurring at higher latitudes and farther east in the La Plata basin.

Acknowledgments. This study is part of the first and third authors' Master of Science Theses at the Graduate Program in Meteorology of the Universidade Federal de Santa Maria (UFSM), in Brazil, funded by the Coordenação de Aperfeiçoamento de Pessoal de Nível Superior under Program Demanda Social. The computing facilities utilized during the development of this study were provided by UFSM's Grupo de Modelagem Atmosférica de Santa Maria. The authors are grateful to 
the three anonymous reviewers and to Chief Editor, Dr. David M. Schultz, for their comments that led to the improvement of the manuscript. We are also grateful to meteorologists Eliton L. Figueiredo, Vanessa Ferreira, and Roilan Hernández Valdés for the helpful discussions and technical assistance during the preparation of the manuscript. The codes utilized to detect LLJs in this study can be requested through the corresponding author email address.

\section{REFERENCES}

Acevedo, O. C., L. P. Pezzi, R. B. Souza, V. Anabor, and G. A. Degrazia, 2010: Atmospheric boundary layer adjustment to the synoptic cycle at the Brazil-Malvinas Confluence, South Atlantic Ocean. J. Geophys. Res., 115, D22107, https://doi.org/ 10.1029/2009JD013785.

Arritt, R. W., T. D. Rink, M. Segal, D. P. Todey, C. A. Clark, M. J. Mitchell, and K. M. Labas, 1997: The Great Plains low-level jet during the warm season of 1993. Mon. Wea. Rev., 125, 2176-2192, https://doi.org/10.1175/1520-0493(1997)125<2176: TGPLLJ $>2.0 . \mathrm{CO} ; 2$.

Berri, G. J., and B. J. Inzunza, 1993: The effect of the low-level jet on the poleward water vapour transport in the central region of South America. Atmos. Environ., 27A, 335-341, https:// doi.org/10.1016/0960-1686(93)90107-A.

Blackadar, A. K., 1957: Boundary layer wind maxima and their significance for the growth of nocturnal inversions. Bull. Amer. Meteor. Soc., 38, 283-290.

Bonner, W. D., 1968: Climatology of the low-level jet. Mon. Wea. Rev., 96, 833-850, https://doi.org/10.1175/1520-0493(1968)096<0833: COTLLJ $>2.0 . \mathrm{CO} ; 2$.

Browning, K. A., and C. W. Pardoe, 1973: Structure of low-level jet streams ahead of mid-latitude cold fronts. Quart. J. Roy. Meteor. Soc., 99, 619-638, https://doi.org/10.1002/qj.49709942204.

Campetella, C. M., and C. S. Vera, 2002: The influence of the Andes mountains on the South American low-level flow. Geophys. Res. Lett., 29, 1826, https://doi.org/10.1029/2002GL015451.

Campos, C. R. J., and J. G. M. Santos, 2007: Seasonal climatology of the low-level jet in the Porto Alegre metropolitan area for the 1989 to 2003 period utilizing rawinsonde data (in Portuguese). Anuar. Inst. Geoc. UFRJ, 30, 83-92, https://revistas.ufrj.br/ index.php/aigeo/article/view/6770.

Chen, R., and L. Tomassini, 2015: The role of moisture in summertime low-level jet formation and associated rainfall over the East Asian monsoon region. J. Atmos. Sci., 72, 3871-3890, https://doi.org/10.1175/JAS-D-15-0064.1.

Doswell, C. A., III, 1991: A review for forecasters on the application of hodographs to forecasting severe thunderstorms. Natl. Wea. Dig., 16, 2-16.

Du, Y., and R. Rotunno, 2014: A simple analytical model of the nocturnal low-level jet over the Great Plains of the United States. J. Atmos. Sci., 71, 3674-3683, https://doi.org/10.1175/ JAS-D-14-0060.1.

—, Q. Zhang, Y. L. Chen, Y. Zhao, and X. Wang, 2014: Numerical simulations of spatial distributions and diurnal variations of low-level jets in China during early summer. J. Climate, 27, 5747-5767, https://doi.org/10.1175/JCLI-D-13-00571.1.

Garratt, J. R., 1985: The inland boundary layer at low latitudes. Part I. The nocturnal jet. Bound.-Layer Meteor., 32, 307-327, https://doi.org/10.1007/BF00121997.
Garreaud, R. D., 2000: Cold air incursions over subtropical South America: Mean structure and dynamics. Mon. Wea. Rev., 128, 2544-2559, https://doi.org/10.1175/1520-0493(2000)128<2544: CAIOSS $>2.0 . \mathrm{CO} ; 2$.

- and R. C. Muñoz, 2005: The low-level jet off the west coast of subtropical South America: Structure and variability. Mon. Wea. Rev., 133, 2246-2261, https://doi.org/10.1175/ MWR2972.1.

Gebauer, J. G., E. Fedorovich, and A. Shapiro, 2017: A 1-D theoretical analysis of the northerly low-level jets over the Great Plains. J. Atmos. Sci., 74, 3419-3431, https://doi.org/10.1175/ JAS-D-16-0333.1.

Hoecker, W. H., 1963: Three southerly low-level jet systems delineated by the weather Bureau Special Pibal Network of 1961. Mon. Wea. Rev., 91, 573-582, https://doi.org/10.1175/15200493(1963)091<0573:TSLJSD>2.3.CO;2.

Holton, J. R., 1967: The diurnal boundary layer wind oscillation above sloping terrain. Tellus, 19, 200-205, https://doi.org/ 10.3402/tellusa.v19i2.9766.

Jiang, X., N. Lau, I. M. Held, and J. J. Ploshay, 2007: Mechanisms of the Great Plains low-level jet as simulated in an AGCM. J. Atmos. Sci., 64, 532-547, https://doi.org/10.1175/JAS3847.1.

Kalnay, E., and Coauthors, 1996: The NCEP/NCAR 40-Year Reanalysis Project. Bull. Amer. Meteor. Soc., 77, 437-471, https:// doi.org/10.1175/1520-0477(1996)077<0437:TNYRP>2.0.CO;2.

Liu, H., M. He, B. Wang, and Q. Zhang, 2014: Advances in low-level jet research and future prospects. J. Meteor. Res., 28, 57-75.

Marengo, J. A., W. R. Soares, C. Saulo, and M. Nicolini, 2004: Climatology of the low-level jet east of the Andes as derived from the NCEP-NCAR reanalyses: Characteristics and temporal variability. J. Climate, 17, 2261-2280, https://doi.org/ 10.1175/1520-0442(2004)017<2261:COTLJE > 2.0.CO;2.

—, M. W. Douglas, and P. L. Silva Dias, 2002: The South American low-level jet east of the Andes during the 1999 LBA-TRMM and LBA-WET AMC campaign. J. Geophys. Res., 107, 8079, https://doi.org/10.1029/2001JD001188.

Markowski, P., and Y. Richardson, 2010: Mesoscale Meteorology in Midlatitudes. Wiley-Blackwell, $424 \mathrm{pp}$.

Montini, T., C. Jones, and L. V. Carvalho, 2016: The South American low-level jet: A new climatology, variability, and changes. 2016 Fall Meeting, San Francisco, CA, Amer. Geophys. Union, Abstract A11N-0198.

Muñoz, R. C., and R. D. Garreaud, 2005: Dynamics of the low-level jet off the west coast of subtropical South America. Mon. Wea. Rev., 133, 3661-3677, https://doi.org/10.1175/MWR3074.1.

Nascimento, E. L., G. Held, and A. M. Gomes, 2014: A multiplevortex tornado in southeastern Brazil. Mon. Wea. Rev., 142, 3017-3037, https://doi.org/10.1175/MWR-D-13-00319.1.

, M. Foss, V. Ferreira, and H. E. Brooks, 2016: An updated and expanded climatology of severe weather parameters for subtropical South America as derived from upper air observations and CFSR-CFSv2 data. 28th Conf. on Severe Local Storms, Portland, OR, Amer. Meteor. Soc., 18.5, https://ams.confex.com/ ams/28SLS/webprogram/Paper300887.html.

Nascimento, M. G., D. L. Herdies, and D. O. Souza, 2016: The South American water balance: The influence of low-level jets. J. Climate, 29, 1429-1449, https://doi.org/10.1175/JCLI-D-15-0065.1.

Nicolini, M., and A. C. Saulo, 2000: Eta characterization of the 1997-1998 warm season Chaco jet cases. Sixth Int. Conf. on Southern Hemisphere Meteorology and Oceanography, Santiago, Chile, Amer. Meteor. Soc., 12C.1, https://ams.confex.com/ams/ other/techprogram/paper_10722.htm. 
_, P. Salio, G. Ulke, J. Marengo, M. Douglas, J. Paegle, and E. Zipser, 2004: South American low-level jet diurnal cycle and three-dimensional structure. CLIVAR Exchanges, Vol. 9, International CLIVAR Project Office, Southampton, United Kingdom, 6-8.

Oliveira, M. I., F. S. Puhales, E. L. Nascimento, and V. Anabor, 2016: Observations and predictability analysis of the 20 April 2015 Xanxere tornado in southern Brazil. 28th Conf. on Severe Local Storms, Portland, OR, Amer. Meteor. Soc., 5, https:// ams.confex.com/ams/28SLS/webprogram/Paper301808.html.

Parish, T. R., 2017: On the forcing of the summertime Great Plains low-level jet. J. Atmos. Sci., 74, 3937-3953, https://doi.org/ 10.1175/JAS-D-17-0059.1.

, and L. D. Oolman, 2010: On the role of sloping terrain in the forcing of the Great Plains low-level jet. J. Atmos. Sci., 67, 2690-2699, https://doi.org/10.1175/2010JAS3368.1.

Pereira, A. P., G. A. Degrazia, O. L. L. Moraes, and T. Tirabassi, 1995: Numerical study of the nocturnal planetary boundary layer at low latitudes. Air Pollution III, Volume 1, Theory and Simulation, C. A. Brebbia, H. Power, and N. Moussiopoulos, Eds., WIT Press, 167-174.

Rasmussen, K. L., and R. A. Houze Jr., 2011: Orogenic convection in subtropical South America as seen by the TRMM satellite. Mon. Wea. Rev., 139, 2399-2420, https://doi.org/10.1175/ MWR-D-10-05006.1.

— , and — 2016: Convective initiation near the Andes in subtropical South America. Mon. Wea. Rev., 144, 2351-2374, https://doi.org/10.1175/MWR-D-15-0058.1.

_ M. D. Zuluaga, and R. A. Houze Jr., 2014: Severe convection and lightning in subtropical South America. Geophys. Res. Lett., 41, 7359-7366, https://doi.org/10.1002/2014GL061767.

Repinaldo, H. F. B., M. Nicolini, and Y. G. Skabar, 2015: Characterizing the diurnal cycle of low-level circulation and convergence using CFSR data in southeastern South America. J. Appl. Meteor. Climatol., 54, 671-690, https://doi.org/10.1175/ JAMC-D-14-0114.1.

Rife, D. L., J. O. Pinto, A. J. Monagham, C. A. Davis, and J. R. Hannan, 2010: Global distribution and characteristics of diurnally varying low-level jets. J. Climate, 23, 5041-5064, https://doi.org/10.1175/2010JCLI3514.1.

Romatschke, U., and R. A. Houze Jr., 2010: Extreme summer convection in South America. J. Climate, 23, 3761-3791, https://doi.org/10.1175/2010JCLI3465.1.

Saha, S., and Coauthors, 2010: The NCEP Climate Forecast System Reanalysis. Bull. Amer. Meteor. Soc., 91, 1015-1057, https:// doi.org/10.1175/2010BAMS3001.1.

Salio, P., M. Nicolini, and A. C. Saulo, 2002: Chaco low-level jet events characterization during the austral summer season. J. Geophys. Res., 107, 4816, https://doi.org/10.1029/2001JD001315.

,-- , and E. J. Zipser, 2007: Mesoscale convective systems over southeastern South America and their relationship with the South American low-level jet. Mon. Wea. Rev., 135, 1290 1309, https://doi.org/10.1175/MWR3305.1.

Saulo, A. C., M. Nicolini, and S. C. Chou, 2000: Model characterization of the South American low-level flow during the 1997-1998 spring-summer season. Climate Dyn., 16, 867-881, https://doi.org/10.1007/s003820000085.

- M. E. Seluchi, and M. Nicolini, 2004: A case study of a Chaco low-level jet event. Mon. Wea. Rev., 132, 2669-2683, https:// doi.org/10.1175/MWR2815.1.

_ J. Ruiz, and Y. G. Skabar, 2007: Synergism between the lowlevel jet and organized convection at its exit region. Mon. Wea. Rev., 135, 1310-1326, https://doi.org/10.1175/MWR3317.1.

Seluchi, M. E., A. C. Saulo, M. Nicolini, and P. Satyamurty, 2003: The northwestern Argentinean low: A study of two typical events. Mon. Wea. Rev., 131, 2361-2378, https://oi.org/ 10.1175/1520-0493(2003)131<2361:TNALAS > 2.0.CO;2.

Shapiro, A., E. Fedorovich, and S. Rahimi, 2016: A unified theory for the Great Plains nocturnal low-level jet. J. Atmos. Sci., 73, 3037-3057, https://doi.org/10.1175/JAS-D-15-0307.1.

Sperling, V. B., 2018: Physical and Electrical Processes in Hailstorms in Southern Brazil (in Portuguese). Ph.D. thesis, Instituto Nacional de Pesquisas Espaciais, São José dos Campos, Brazil, 187 pp.

Stensrud, D. J., 1996: Importance of low-level jets to climate: A review. J. Climate, 9, 1698-1711, https://doi.org/10.1175/15200442(1996)009<1698:IOLLJT>2.0.CO;2.

Teixeira, M. S., and P. Satyamurty, 2007: Dynamical and synoptic characteristics of heavy rainfall episodes in Southern Brazil. Mon. Wea. Rev., 135, 598-617, https://doi.org/ 10.1175/MWR3302.1.

Uccellini, L. W., 1980: On the role of upper tropospheric jet streaks and leeside cyclogenesis in the development of low-level jets in the Great Plains. Mon. Wea. Rev., 108, 1689-1696, https://doi.org/10.1175/1520-0493(1980)108<1689: OTROUT $>2.0 . \mathrm{CO} ; 2$.

Vera, C., P. K. Vigliarolo, and E. H. Berbery, 2002: Cold-season synoptic scale waves over subtropical South America. Mon. Wea. Rev., 130, 684-699, https://doi.org/10.1175/1520-0493(2002) 130<0684:CSSSWO $>2.0 . \mathrm{CO} ; 2$.

_ , and Coauthors, 2006: The South American low-level jet experiment. Bull. Amer. Meteor. Soc., 87, 63-77, https://doi.org/ 10.1175/BAMS-87-1-63.

Weykamp, F. V., and T. Ambrizzi, 2006: The role of the low-level jet east of the Andes in extreme rainfall events over southern South America. Eighth Int. Conf. on Southern Hemisphere Meteorology and Oceanography, Foz do Iguaçu, Brazil, Amer. Meteor. Soc., 1231-1234.

Whiteman, C. D., X. Bian, and S. Zhong, 1997: Low-level jet climatology from enhanced rawinsonde observations at a site in the southern Great Plains. J. Appl. Meteor., 36, 1363-1376, https:// doi.org/10.1175/1520-0450(1997)036<1363:LLJCFE > 2.0.CO;2. 